ARTICLE

DOI: $10.1038 / s 41467-018-03382-x$

\title{
Germinal center entry not selection of B cells is controlled by peptide-MHCII complex density
}

Chen-Hao Yeh (1) ${ }^{1}$, Takuya Nojima ${ }^{1}$ Masayuki Kuraoka ${ }^{1} \&$ Garnett Kelsoe ${ }^{1,2}$

B cells expressing high affinity antigen receptors are advantaged in germinal centers (GC), perhaps by increased acquisition of antigen for presentation to follicular helper $T$ cells and improved T-cell help. In this model for affinity-dependent selection, the density of peptide/ $\mathrm{MHCII}$ (pMHCII) complexes on GC B cells is the primary determinant of selection. Here we show in chimeric mice populated by $\mathrm{B}$ cells differing only in their capacity to express $\mathrm{MHCII}$ $\left(\mathrm{MHCll}^{+/+}\right.$and $\left.\mathrm{MHCll}^{+/-}\right)$that $\mathrm{GC}$ selection is insensitive to halving $\mathrm{pMHCll}$ density. Alone, both $\mathrm{B}$ cell types generate identical humoral responses; in competition, $\mathrm{MHCII}^{+/+} \mathrm{B}$ cells are preferentially recruited to early $\mathrm{GCs}$ but this advantage does not persist once GCs are established. During $\mathrm{GC}$ responses, competing $\mathrm{MHCll}^{+/+}$and $\mathrm{MHClI}^{+/-} \mathrm{GC}$ B cells comparably accumulate mutations and have indistinguishable rates of affinity maturation. We conclude that B-cell selection by $\mathrm{pMHCII}$ density is stringent in the establishment of GCs, but relaxed during GC responses.

\footnotetext{
${ }^{1}$ Department of Immunology, Duke University School of Medicine, Durham, NC 27710, USA. ${ }^{2}$ Duke University Human Vaccine Institute, Duke University School of Medicine, Durham, NC 27710, USA. Correspondence and requests for materials should be addressed to G.K. (email: ghkelsoe@duke.edu)
} 
T he primary repertoire of $\mathrm{B}$-cell antigen receptors $(\mathrm{BCR})$ is generated by the combinatorial association of $\mathrm{V}, \mathrm{D}$, and $\mathrm{J}$ gene segments during B-cell development. This primary $B C R$ repertoire is expanded and refined by somatic hypermutation and affinity-driven selection in germinal centers (GC), resulting in a secondary BCR repertoire capable of high affinity binding to virtually any antigen. Selection for entry into nascent GCs seems to be controlled by interclonal competition for T-cell help based on the different levels of peptide/MHC class II (pMHCII) displayed by antigen-activated B cells ${ }^{1}$. Concordantly, even B cells expressing BCRs with very low affinity for antigen can form GCs in the absence of competition from higher-affinity clones ${ }^{2,3}$. In organized GCs, B cells participate in iterative rounds of interzonal migration, switching between the centroblast state in the GC dark zone (DZ) and the centrocyte state in the light zone (LZ) ${ }^{4}$. Rapid proliferation and fixation of $\mathrm{V}(\mathrm{D}) \mathrm{J}$ mutations characterize the GC DZ, whereas antigen presentation and affinity-dependent selection occur among the $\mathrm{T}_{\mathrm{FH}}$ and follicular dendritic cells (FDC) in the $\mathrm{LZ}^{5,6}$. Selection in the LZ is thought to represent intraclonal and interclonal competition; the successful B-cell competitors return to the DZ for additional rounds of proliferation and mutation and by this cyclic process maximize the somatic evolution of $\mathrm{BCR}$ affinity ${ }^{7-10}$. How FDC and $\mathrm{T}_{\mathrm{FH}}$ cells function to select higher affinity BCRs from newly mutated B-cell populations, however, is unclear.

Affinity-driven selection in GCs has been proposed to be controlled by the density of pMHCII displayed by B cells during cognate interaction with helper T cells ${ }^{4}$. This " $\mathrm{T}$-cell help" model is supported by mathematical modeling ${ }^{11}, 12$, the finding that BCRs retrieve antigen for processing in an affinity-dependent manner ${ }^{13}$, and the critical function of $\mathrm{T}_{\mathrm{FH}}$ cells in GC responses ${ }^{14}$. Direct evidence for the role of pMHCII density in controlling GC B-cell competition comes from experiments that deliver antigen to GC $B$ cells by a BCRindependent mechanism that bypasses $\mathrm{FDCs}^{5}, 9,15,16$. In this experimental model, targeted LZ B cells with increased pMHCII densities have prolonged interaction with $\mathrm{T}_{\mathrm{FH}}$ cells and preferentially re-enter the DZ for further rounds of proliferation and mutation ${ }^{5}$. These studies also indicate that prolonged, cognate T:B-cell interaction increases the proliferative capacity of GC B cells in the DZ and speeds transit through the cell cycle, 15,16 .

To quantify the role of pMHCII in controlling B-cell selection into and during the GC reaction, we use an alternative strategy to map the limits of T-cell help in the selection of antigen-specific $\mathrm{B}$ cells for humoral responses. By short- and long-term B-cell reconstitutions, we place congenic $\mathrm{MHCII}^{+/+}$and haploinsufficient $\mathrm{MHCII}^{+-} \mathrm{B}$ cells in direct competition for GC entry and affinity-dependent selection. Even though MHCII expression by $\mathrm{B}$ cells is modulated during the course of humoral responses, these competing B-cell populations consistently express twofold differences in MHCII and pMHCII surface density. Our competition experiments confirm that $\mathrm{MHCII}^{+/+} \mathrm{B}$ cells are preferentially seeded to nascent GCs even though wild type (WT) and haploinsufficient B cells are comparably activated by antigen in vivo. Once GCs are formed, however, $\mathrm{MHCII}^{+/+} \mathrm{GC}$ B cells have no competitive advantage over haploinsufficient $B$ cells with regard to their persistence, proliferation, acquisition of $\mathrm{V}(\mathrm{D}) \mathrm{J}$ mutations, and affinity maturation. We conclude that pMHCIIdriven selection is more stringent for B cells entering GCs than for B cells in established GCs. In this relaxed environment of pMHCII selection, GC B cells with a broad range of BCR affinities can co-exist, increasing the potential for rare evolutionary trajectories to contribute to protective, humoral immunity.

\section{Results}

MHCII haploinsufficiency does not impair GC responses. Cognate $T: B$ interaction is essential for the initiation and maintenance of GC responses ${ }^{17,} 18$ and the efficacy of these interactions correlates with the quantity of antigen acquired by the B-cell partner ${ }^{1}$. ${ }^{5}$. Rather than by introducing targeted antigen ${ }^{1,9}$, we chose to regulate the availability of pMHCII for cognate $\mathrm{T}: \mathrm{B}$ interaction by using congenic mice hemizygous for the MHCII locus $\left(\mathrm{MHCII}^{+/-}\right)^{19}$. To quantify the effect of MHCII hemizygosity in various activation states, congenic $\mathrm{MHCII}^{+/+}$ and $\mathrm{MHCII}^{+/-} \mathrm{B} 6$ mice were immunized intraperitoneally (i.p.) with (4-hydroxy-3-nitrophenyl)acetyl (NP)-conjugated ovalbumin (NP-OVA) in alum. Compared with B6 $\mathrm{MHCII}^{+/+}$ B cells, $\mathrm{MHCII}^{+/-} \mathrm{B}$ cells exhibit a haploinsufficiency that reduces MHCII expression by half, on naive, mature follicular (MF; $\mathrm{B} 220^{+} \mathrm{CD}^{-} 3^{-} \mathrm{IgD}{ }^{+} \mathrm{CD} 138^{-} \mathrm{CD} 38^{\text {hi }} \mathrm{GL}-7^{-}$) and GC B cells $\left(\mathrm{B} 220^{+} \mathrm{CD} 38^{\text {low }} \mathrm{GL}^{+} \mathrm{CD} 95^{+}\right)$, including GC B cells in the $\mathrm{LZ}$ $\left(\mathrm{CXCR} 4^{\text {low }}{ }^{\mathrm{CD}} 86^{\mathrm{hi}}\right)$ and $\mathrm{DZ}\left(\mathrm{CXCR} 4^{\mathrm{hi}} \mathrm{CD} 86^{\mathrm{low}}\right)$ compartments (Fig. 1a).

To ensure that MHCII haploinsufficiency equated to a comparable reduction in pMHCIIs, we made a chimeric antigen of NP-streptavidin bound to biotinylated I-Ea52-73 peptide (NPSA-Ea $)^{1}$. Quantification of Ea52-68 pMHCII complexes can be determined by the $\mathrm{Y}-\mathrm{Ae}$ monoclonal $\mathrm{Ab}$, which is specific for pEa:I-A ${ }^{\mathrm{b}}$ complexes $^{20}$. B1-8.MHCII ${ }^{+/+}$and B1-8.MHCII ${ }^{+/-}$ mice were immunized in the footpad with NP-SA-E $\alpha$ in alum; MHCII expression on MF B cells in unimmunized controls was halved in haploinsufficient animals, for both NP-binding and non-binding cells (Supplementary Fig. 1A). In immunized mice, by $16 \mathrm{~h}$ post immunization populations of NP-binding $\mathrm{B}$ cells with lower membrane IgD levels appeared in both WT and haploinsufficient mice (Fig. 1b). Within these activated $\mathrm{IgD}^{\text {low }} \mathrm{NP}^{+}$B-cell subsets, both MHCII and Ea52-68 pMHCII were halved in $\mathrm{MHCII}^{+/-} \mathrm{B}$ cells compared to WT controls. This quantitative difference is maintained when B cells are exposed to TLR ligands in vitro (Supplementary Figs. 1B-D).

We observed no significant effects of MHCII haploinsufficiency on T-cell-dependent humoral responses. $\mathrm{MHCII}^{+/+}$and $\mathrm{MHCII}^{+-}$B6 mice immunized with NP-OVA exhibited comparable IgG Ab levels and GC responses on days 8, 12, 16, and 24 post immunization. Indeed, the kinetics and magnitude of GC responses in $\mathrm{MHCII}^{+/+}$and $\mathrm{MHCII}^{+/-}$mice were indistinguishable (Fig. 1c) and serum IgG for NP and NIP (4-hydroxy-3-iodo-5-nitrophenyl acetyl) were similar as well (Fig. 1d). As expected ${ }^{21}$, heteroclitic (NIP-binding) IgG levels rose faster than NP-specific IgG, but NP- and NIP-specific serum IgG levels converged by day 24 (Fig. 1d). These data demonstrate that $\mathrm{MHCII}^{+/+}$and $\mathrm{MHCII}^{+/-} \mathrm{B}$ cells have similar intrinsic capacities to produce GCs and serum IgG Ab in response to NPOVA. In the absence of $\mathrm{MHCII}^{+/+}$competitors, reduced MHCII and pMHCII expression on haploinsufficient B cells does not impact GC responses or affinity maturation of serum IgG Ab.

To determine whether MHCII haploinsufficiency might affect the average or distribution of BCR avidities within GCs, we sorted single MF and GC B cells from the spleens of $\mathrm{MHCII}^{+/+}$and $\mathrm{MHCII}^{+/-}$mice immunized with NP-OVA for single-cell Nojima cultures (Supplementary Fig. 2A) ${ }^{22}$. Eight days post immunization, we obtained a total of 1107 clonal $\mathrm{IgG}^{+}$Nojima cultures. From $\mathrm{MHCII}^{+/+}$mice, we recovered $223 \mathrm{MF}$ and 349 $\mathrm{GC} \mathrm{IgG}^{+}$cultures for cloning efficiencies of $73.4 \%$ (223/304) and 28.7\% (349/1216), respectively. From haploinsufficient, $\mathrm{MHCII}^{+1-}$ mice we obtained $227 \mathrm{MF}$ and $308 \mathrm{GC} \mathrm{IgG}^{+}$singlecell cultures with cloning efficiencies of $74.7 \%$ (227/304) and $25.3 \%$ (308/1216). Similar cloning efficiencies for WT and haploinsufficient MF and GC B cells indicate that MHCII expression levels do not affect MF or GC B-cell survival, proliferation, and plasmacytic differentiation in Nojima cultures.

To compare BCR affinity distributions among GC B cells from $\mathrm{MHCII}^{+/+}$and $\mathrm{MHCII}^{+/-}$mice, we determined the avidity 
indices (AvIns) for every clonal IgG Nojima culture to NP and $\mathrm{NIP}^{22}$. The AvIn represents the ratio of specific (NP- or NIP) binding by individual clonal IgGs to a standard, heteroclitic NP/ NIP IgG mAb, H33L $\gamma 1\left(K_{\mathrm{a}}=2.0 \times 10^{7} \mathrm{M}^{-1}\right)^{21}$. We determined AvIn values for both high density (permissive) and low density (stringent), NP- and NIP-binding. The expected, canonical GC response is both heteroclitic (NIP $>$ NP binding) and stringent. From $\mathrm{MHCII}^{+/+}$and $\mathrm{MHCII}^{+/-}$GC, respectively, 44.7\% (155/ $349)$ and $60.3 \%$ (186/308) of clonal IgGs bound to the permissive (low and high avidity), high-density $\mathrm{NIP}_{25}$ conjugated Luminex beads; both cohorts exhibited similar AvIn distributions and geometric means that were not significantly different (Fig. 1e). Stringent, heteroclitic binding to $\mathrm{NIP}_{2}$ conjugated beads was also identical between the $\mathrm{MHCII}^{+/+}$and $\mathrm{MHCII}^{+/-}$cohorts with similar distributions and geometric means of AvIn values that were comparably higher than those determined for $\mathrm{NP}_{2}$ beads (Fig. 1e). In no case did the mean AvIn values for $\mathrm{MHCII}^{+/+} \mathrm{GC}$ and $\mathrm{MHCII}^{+/-}$GC B cells differ significantly for the same

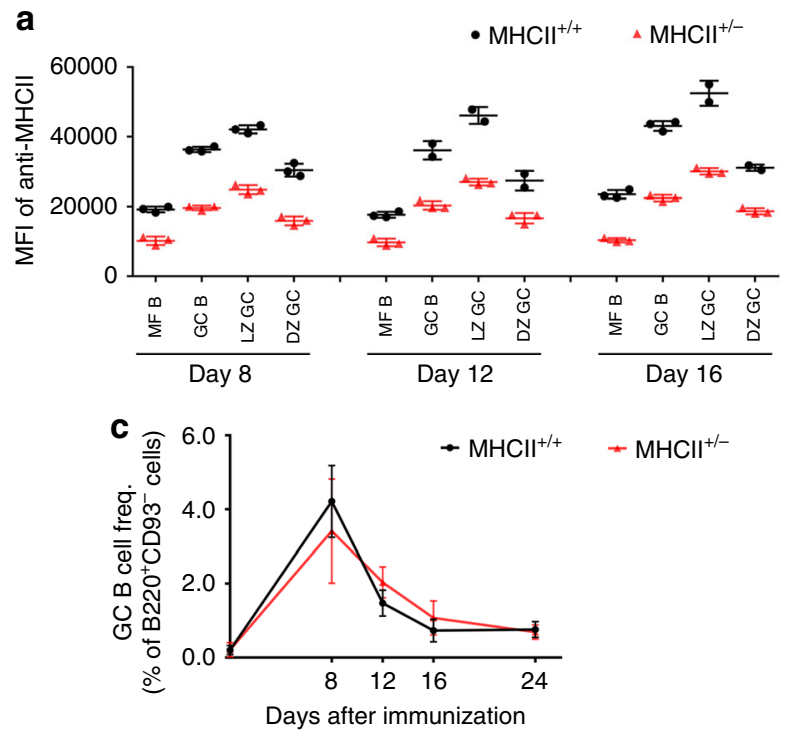

e
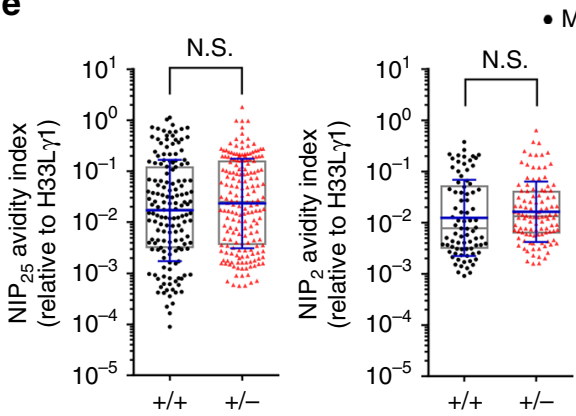

- $\mathrm{MHClI}^{+/+} \quad \triangle \mathrm{MHClI}^{+/-}$

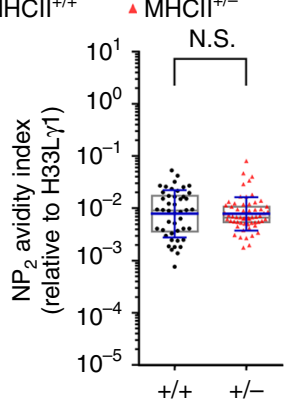

antigen ligand and both WT and haploinsufficient GC B-cell clones exhibited comparable heteroclicity (twofold relative to $\mathrm{H} 33 \mathrm{~L} \gamma 1)$ for $\mathrm{NIP}_{2}$ over $\mathrm{NP}_{2}$ (Fig. 1e). We conclude that even at the level of individual GC B-cell clones, MHCII haploinsufficiency has little or no effect on primary GC B-cell responses to NP-OVA.

$\mathrm{MHCII}^{+/+}$B cells are preferentially recruited into GC responses. Given their identical, intrinsic capacities for humoral responses, we sought to determine whether $\mathrm{MHCII}^{+/-} \mathrm{B}$ cells would exhibit lower competitive fitness against $\mathrm{MHCII}^{+/+}$competitors. Consequently, we transferred $\left(2 \times 10^{6}\right)$ MF B cells from congenic $\mathrm{CD} 45.1^{+} \mathrm{B} 1-8^{+/+} \mathrm{MHCII}^{+/+}$and $\mathrm{CD} 45.2^{+} \mathrm{B}^{-8^{+/+}} \mathrm{MHCII}^{+/-}$mice into (B6.SJL $\times$ B6) $\mathrm{F}_{1}\left(\mathrm{CD} 45.1^{+} / \mathrm{CD} 45.2^{+}\right)$recipients (Fig. 2a). The B1-8 VDJ knock-in homogenizes the BCR affinities in both donor cell populations and ensures their activation and competition in response to NP-OVA antigen ${ }^{23}$. Soon after cell transfer (12-16 h), recipient mice were immunized i.p. with NP-OVA in alum.

b
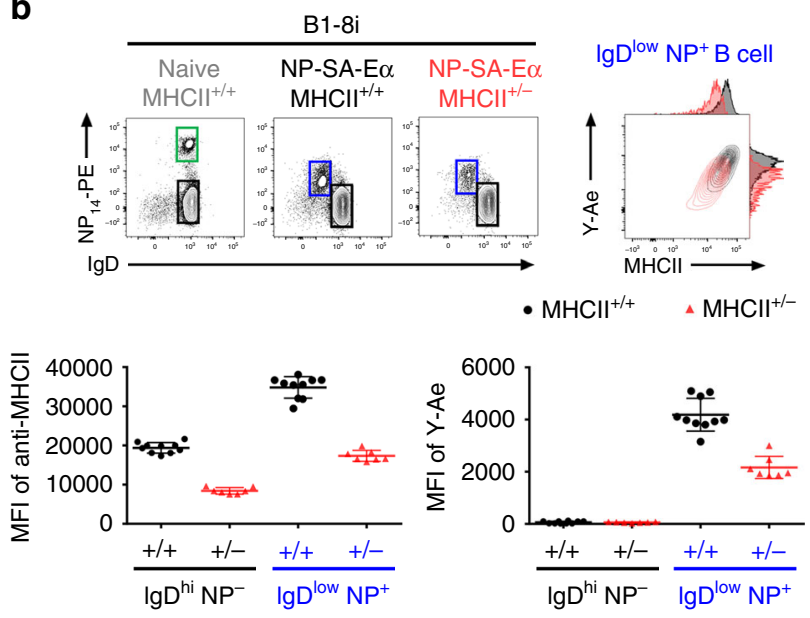

d

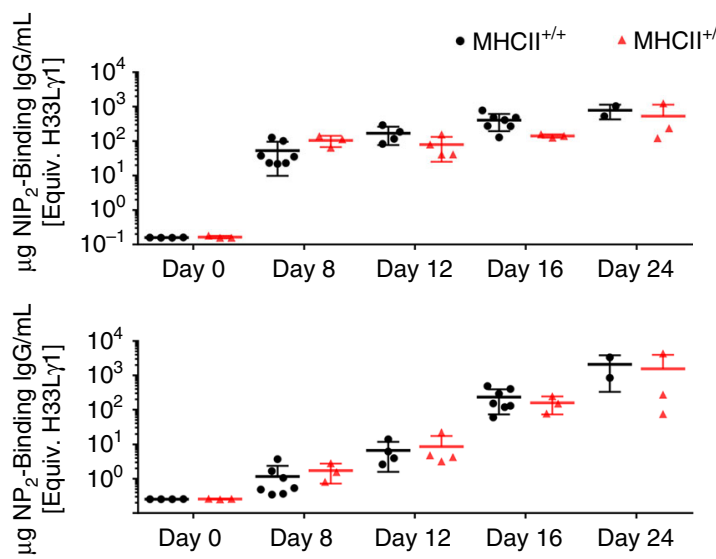

Fig. $1 \mathrm{MHCll}$ haploinsufficiency supports normal GC kinetics and affinity maturation. $\mathrm{MHCll}^{+/+}$(black circles) and $\mathrm{MHCll}^{+/-}$(red triangles) mice were immunized i.p. with $20 \mu \mathrm{g}$ of NP-OVA in alum (a, c, d, e). a MHCll expression on MF B, GC B, LZ GC B, and DZ GC B cells harvested as indicated post immunization. b B1-8.MHCII ${ }^{+/}$and B1-8.MHCII ${ }^{+/-}$mice were immunized in the footpad with $20 \mu \mathrm{g}$ NP-SA-E $\alpha$ in alum. Cells from popliteal LNs were

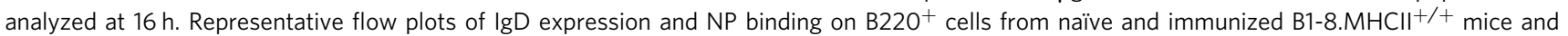
immunized B1-8. $\mathrm{MHCll}^{+/}$- mice are shown. Contour plots and histograms representing MHCll expression and Y-Ae-binding (E $\alpha$ peptide:MHCll complex) on $\mathrm{IgD}^{\text {low }} \mathrm{NP}^{+} \mathrm{B} 22 \mathrm{O}^{+}$cells from B1-8. $\mathrm{MHClI}^{+/+}$(black) and B1-8.MHCII+/- (red) mice. Lower panels show MHCIl expression as MFI (left) and Y-Aebinding (right) in B-cell compartments. c Kinetics of $\mathrm{GC}$ responses in immunized $\mathrm{MHCll}^{+/+}$and $\mathrm{MHCII}^{+/-}$mice $(n=2-5$ for both strains at each time point; mean \pm S.D.). d Kinetics of serum $\operatorname{lgG}$ responses (top, $\mathrm{NIP}_{2}$-binding lgG; bottom, $\mathrm{NP}_{2}$-binding $\operatorname{lgG}$ ) in $\mathrm{MHCII}^{+/+}$and $\mathrm{MHCII}{ }^{+/-}$mice. $\operatorname{lgG}$ concentrations were determined in a Luminex assay in reference to $\mathrm{mAb} H 33 \mathrm{~L} \gamma$. Each point represents a single mouse with means ( \pm S.D.) indicated. e Single-cell, Nojima cultures for day $8 \mathrm{GC}$ B cells; $\mathrm{NIP}_{25^{-}}, \mathrm{NIP}_{2^{-}}$and $\mathrm{NP}_{2}$-specific AvIn values (relative to mAb H33L $\gamma 1$ ) are shown ${ }^{22}$. Each point represents one $\mathrm{lgG}^{+}$clonal culture $(n=45-187)$; boxes represent the 25 th, 75 th percentiles and median. Bars (blue) indicate the geometric means \pm S.D. Statistical significance $(P<0.05)$ was measured by the Mann-Whitney $U$ test 
a
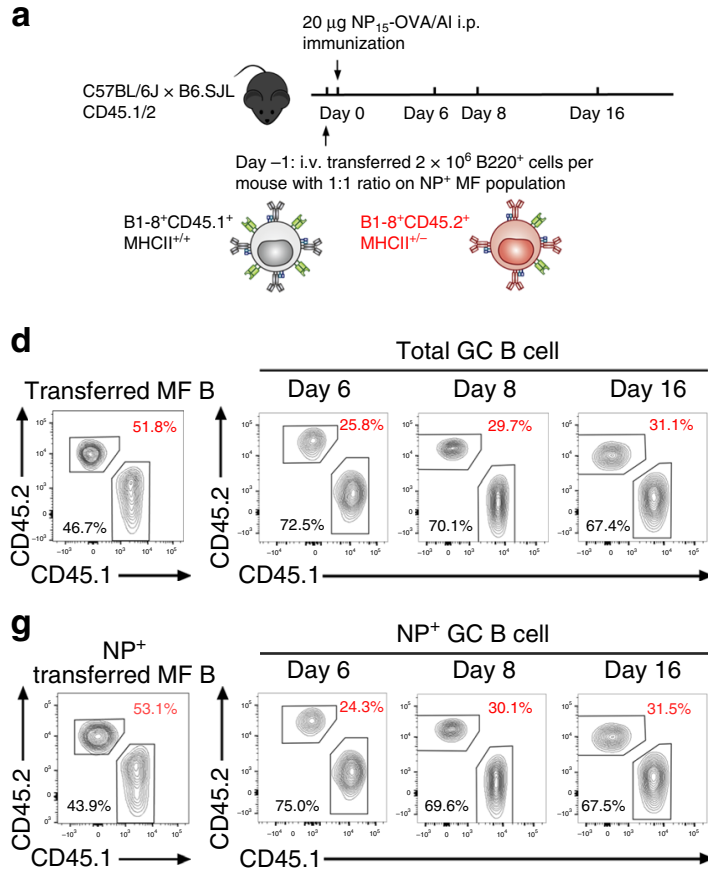

j

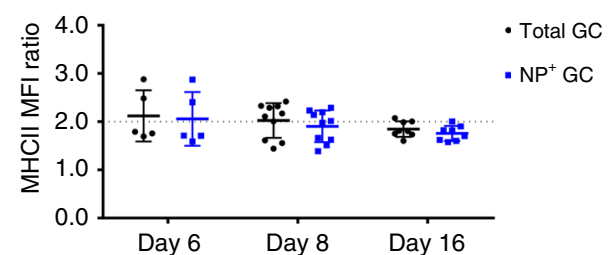

b

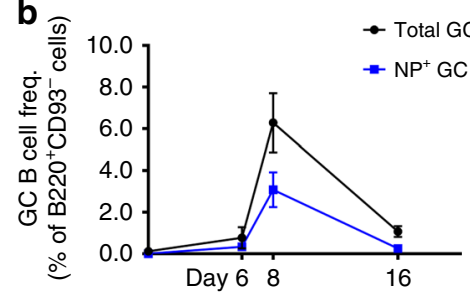

e

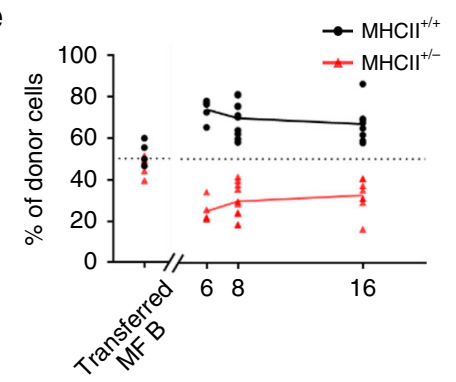

h

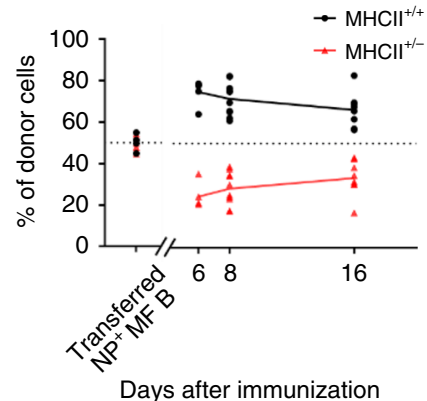

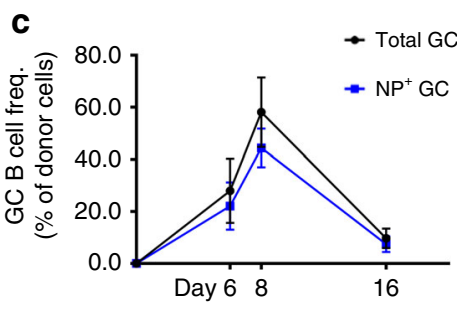

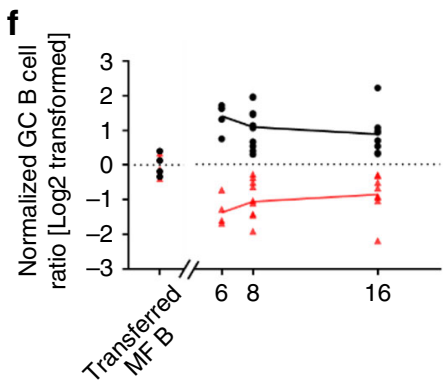

i

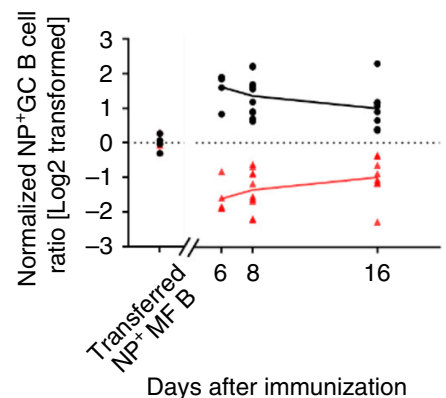

Fig. $2 \mathrm{MHCll}^{+/+} \mathrm{B}$ cells are advantaged in populating early GCs. a Diagrammatic representation of the experimental design. Recipient mice (CD45.1 $1^{+}$ CD $\left.45.2^{+}\right)$received i.v. transfers of $1: 1$ mixtures of NP-reactive, congenically marked B1-8.MHCII+/+ $\left(\mathrm{CD} 45.1^{+}\right)$and $\mathrm{B} 1-8 . \mathrm{MHCll}{ }^{+/-}\left(\mathrm{CD} 45.2^{+}\right) \mathrm{B}$ cells on day -1 . These mice were subsequently immunized i.p. with NP-OVA in alum (day 0 ). Splenocytes were harvested, labeled and examined by flow cytometry on days 0 (naïve), 6, 8, and 16 post immunization. b, c Kinetics of $\mathbf{b}$ total and $\mathbf{c}$ donor only GC and NP+ GC responses. d-f Proportions of B1-8. $\mathrm{MHCII}^{+/+}$and B1-8.MHCII ${ }^{+/-}$cells within donor-derived total GC B-cell compartments. $\mathbf{d}$ Representative flow diagrams, e combined results and $\mathbf{f}$ normalized kinetics from three independent experiments are shown. g-i Proportions of B1-8. $\mathrm{MHCI}^{+/+}$and B1-8.MHCII ${ }^{+/-}$cells within donor-derived NPbinding GC B-cell compartments. $\mathbf{g}$ Representative flow diagrams, $\mathbf{h}$ combined results, and $\mathbf{i}$ normalized kinetics from three independent experiments are shown. Numbers indicate the frequencies of cells from B1-8.MHCII ${ }^{+/+}\left(\mathrm{CD} 45.1^{+}\right.$, black) and B1-8.MHCII ${ }^{+/-}$(CD45.2 ${ }^{+}$, red) donors (d, $\left.\mathbf{g}\right)$. Symbols represent the frequencies of $\mathrm{CD} 45.1^{+} \mathrm{B} 1-8 . \mathrm{MHClI}{ }^{+/+}$(black circles) or $\mathrm{CD} 45.2^{+} \mathrm{B} 1-8 . \mathrm{MHCll}^{+/-}$(red triangles) cells among each $\mathrm{B}-$ cell compartment of donor cells $(\mathbf{e}, \mathbf{h})$. To normalize against B-cell chimerism variations in individual recipient animals, donor ratios of $\mathrm{MHCll}^{+/+}: \mathrm{MHCII}^{+/-}$in $\mathrm{GC} \mathrm{B}$ cells were normalized to the donor ratios of $\mathrm{MHCll}^{+/+}: \mathrm{MHCII}^{+/-}$in $\mathrm{MF} \mathrm{B}$ cells (homo/hemi; black). Similarly, donor ratios of $\mathrm{MHCll}^{+/-}: \mathrm{MHCll}^{+/+}$in $\mathrm{GC} B$ cells were normalized to the donor ratios of $\mathrm{MHCII}^{+/-}: \mathrm{MHCII}^{+/+}$in $\mathrm{MF} \mathrm{B}$ cells (hemi/homo; red) (f, i). $\mathbf{j}$ The ratio of $\mathrm{MHCll} \mathrm{MFI} \mathrm{values} \mathrm{on} \mathrm{MHCll}^{+/+}$donors over $\mathrm{MHCII}^{+/-}$donors (total GC B cells, black circles; $\mathrm{NP}^{+} \mathrm{GC}$ B cells, blue squares). Each symbol represents an individual mouse from at least three independent experiments ( $n=5-10$ at each time point) and the bars indicate the mean values ( \pm S.D.) of each group. The cell populations and gatings were defined as Supplementary Fig. 2

Competition between $\mathrm{CD} 45.1^{+} \mathrm{MHCII}^{+/+}$and $\mathrm{CD} 45.2^{+} \mathrm{MHCII}^{+/-}$ splenic B cells was monitored by flow cytometry on days 6,8 , and 16 post immunization (Fig. 2b,c and Supplementary Fig. 2).

Analysis of transferred $\mathrm{B}$ cells confirmed a near 1:1 ratio of $\mathrm{B} 1-8^{+/+} \mathrm{MHCII}^{+/+}$and $\mathrm{B} 1-8^{+/+} \mathrm{MHCII}^{+/-}$MF $\mathrm{B}$ cells in recipient mice $\left[n=23 ; \mathrm{CD}^{2} 5.1^{+} \mathrm{MHCII}^{+/+} 52.8( \pm 5.9) \%\right.$ and CD45.2 $2^{+} \mathrm{MHCII}^{+/-} 46.1( \pm 5.3) \%$, respectively] (Fig. 2d). Six days post immunization, low frequencies $[0.73( \pm 0.25) \%]$ of GC phenotype B cells (Supplementary Fig. 2) were observed in the spleens of immunized recipients, representing initiation of detectable GC responses (Fig. 2b). Passively transferred, $\mathrm{CD} 45.1^{+} \mathrm{MHCII}^{+/+} \mathrm{B}$ cells exhibited a significant selective advantage over $\mathrm{CD} 45.2^{+} \mathrm{MHCII}^{+/-}$competitors for acquisition of the GC phenotype; on day 6, the ratio of $\mathrm{MHCII}^{++}[70.9$ $( \pm 5.2) \%]$ to $\mathrm{MHCII}^{+/-}[28.0( \pm 5.5) \%]$ cells with GC phenotype was approximately 2:1 (Fig. $2 \mathrm{~d}-\mathrm{f}$ ). By day 8 , the splenic GC compartment expanded almost tenfold, to $6.3( \pm 1.4) \%$ of all mature $\mathrm{B}$ cells $\left(\mathrm{B} 220^{+} \mathrm{CD} 93^{-}\right)$, but the $2: 1$ ratio of $\mathrm{MHCII}^{+/+}$ $[69.7( \pm 8.5) \%]$ to $\mathrm{MHCII}^{+/-}[29.8( \pm 8.5) \%]$ transferred GC B cells remained essentially constant (Fig. $2 \mathrm{~d}-\mathrm{f}$ ). Indeed, this $2: 1$ ratio was maintained to day $16[66.9( \pm 9.0) \%$ and $32.7 \pm(8.0) \%]$ even as GC responses waned to $1.1( \pm 0.3) \%$ of the mature B-cell compartment. Interestingly, although the fitness advantage of $\mathrm{MHCII}^{+/+}$vs. $\mathrm{MHCII}^{+/-} \mathrm{GC} \mathrm{B}$ cells did not change significantly over time, bias for $\mathrm{MHCII}^{+/+} \mathrm{B}$ cells at day 6 (2.6:1) fell slightly on days 8 and 16 (2.3:1) (Fig. 2d-f).

To determine whether transferred $\mathrm{MHCII}^{+/+}$and $\mathrm{MHCII}^{+/-}$ B cells are comparably activated by immunogen in vivo, we immunized (footpad) transferred mice with NP-SA-Ea in alum. By $16 \mathrm{~h}$ post immunization, equivalent populations of IgD ${ }^{\text {low }} \mathrm{NP}^{+}$ B cells were present in both $\mathrm{MHCII}^{+/+}$and $\mathrm{MHCII}^{+/-}$donor cell compartments (Supplementary Fig. 3A) and ratios of activated and resting $\mathrm{MHCII}^{+/+}$and $\mathrm{MHCII}^{+/-} \mathrm{B}$ cells were identical in immunized and control mice (Supplementary 

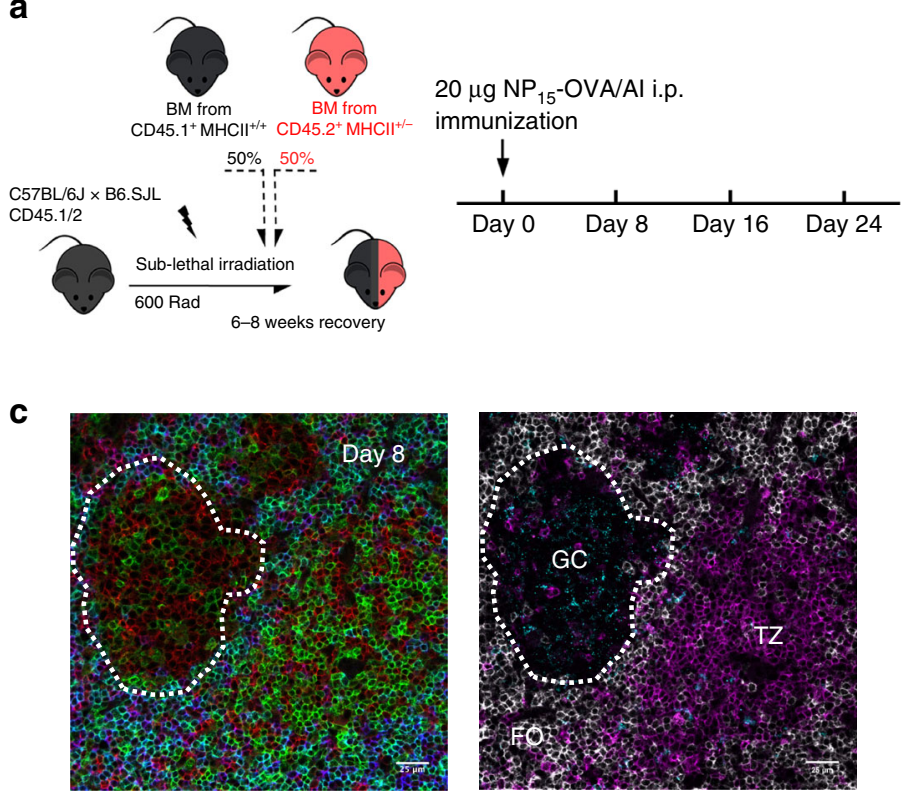

e

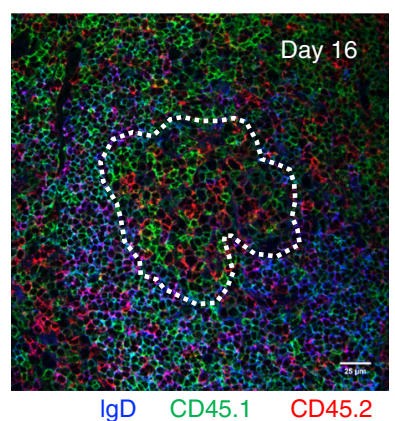

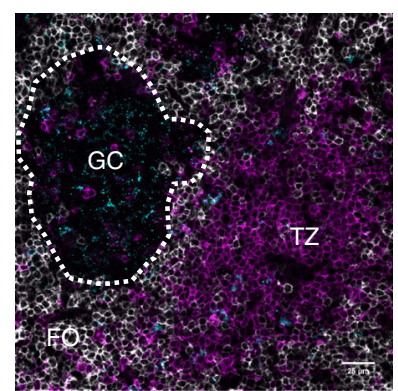

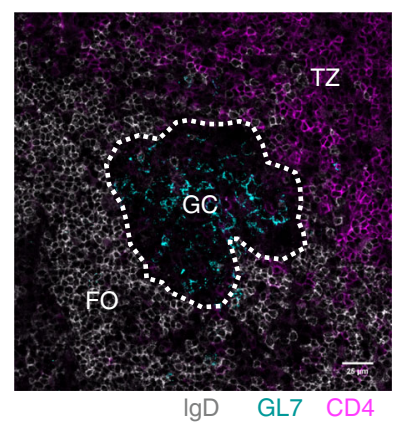

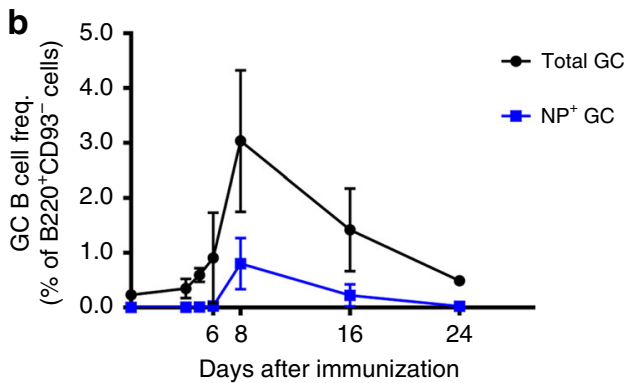

d

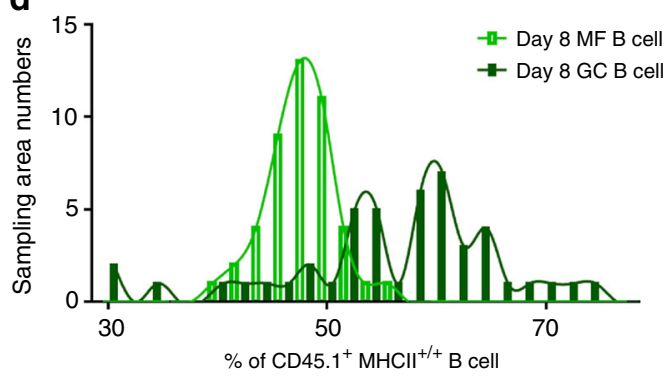

f

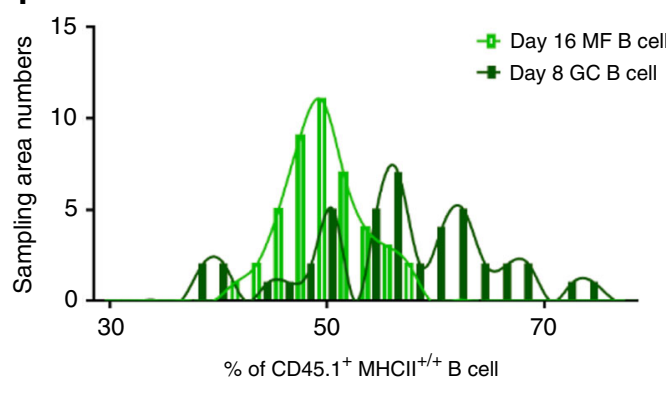

Fig. $3 \mathrm{MHCll}^{+/+}$and $\mathrm{MHClI}^{+/-}$B cells directly compete in GCs. a Diagrammatic representation of the experimental design. Sublethally irradiated, recipient mice $\left(\mathrm{CD} 45.1^{+} \mathrm{CD} 45.2^{+}\right)$were reconstituted with a 1:1 ratio of $\mathrm{BM}$ cells from $\mathrm{MHClI}^{+/+}\left(\mathrm{CD} 45.1^{+}\right)$and $\mathrm{MHCII}{ }^{+/-}\left(\mathrm{CD} 45.2^{+}\right)$mice. Six to eight weeks after reconstitution, chimeric mice were immunized i.p. with $20 \mu \mathrm{g} N \mathrm{~N}$-OVA in alum. Splenocytes were harvested, stained and examined by flow cytometry on days 4-24 post immunization. $\mathbf{b}$ Kinetics of GC B-cell responses are shown (total GC B cells, black circles; NP ${ }^{+}$GC B cells, blue squares; $n=$ 3-13 for both strains at each time point; mean \pm S.D.). c-f Frozen sections from the spleen of day 8 (c, $\mathbf{d}$ ) and day 16 (e, f) chimeras were examined by IHC: IgD (blue and gray), CD45.1 ( $\mathrm{MHCII}^{+/+}$; green), CD45.2 (MHCII+/-; red), GL7 (cyan), and CD4 (magenta). FO follicle, GC germinal center, TZ T-cell zone. Original magnification: $\times 200$, scale bars indicate $25 \mu \mathrm{m}$. d, f Plots represent the distribution of $\mathrm{CD} 45.1^{+} \mathrm{MHCII}+/+B$ cells frequency in follicular areas (light green) or GC areas (dark green). Follicular areas $(50 \times 50 \mu \mathrm{m} ; n=44-46$ from 22-23 follicles; 2 mice per time point) or $\mathrm{GC}$ areas $(50 \times 50 \mu \mathrm{m} ; n=$ 44-46 from 22-23 GCs; $N=2$ mice per time point) were chosen randomly

Figs. 3B and 3C). We conclude that even in direct competition, $\mathrm{MHCII}^{+/+}$and $\mathrm{MHCII}^{+/-} \mathrm{B}$ cells are comparably activated by exposure to antigen. Crucially, $\mathrm{MHCII}^{+/-} \mathrm{IgD}^{\text {low }} \mathrm{NP}^{+} \mathrm{B}$ cells labeled with the Y-Ae mAb were exactly half as bright as WT controls, demonstrating that MHCII and pMHCII are equally reduced in haploinsufficient B cells (Supplementary Figs. 3D and 3E). Lower pMHCII levels on MF B cells do not impair initial activation by antigen.

To ensure that the early fitness advantage of transferred $\mathrm{MHCII}^{+/+} \mathrm{B}$ cells in the GC response included NP-specific cells, we determined the ratios of NP-binding, CD45.1 $\mathrm{MHCII}^{+/+}$ and $\mathrm{CD} 45.2 \mathrm{MHCII}^{+l-} \mathrm{B}$ cells in the splenic GC compartment (Fig. $2 \mathrm{~g}$ ). This analysis confirmed a nearly $1: 1$ ratio $[50.2( \pm 4.2) \%$ and $49.0( \pm 4.0) \%$, respectively] of NP-reactive $\mathrm{B} 1-8^{+/+} \mathrm{MHCII}^{+/+}$ and $\mathrm{B} 1-8^{+/+} \mathrm{MHCII}^{+/-} \mathrm{MF} \mathrm{B}$ cells were transferred; by day 6 after immunization, however, NP-binding, CD45.1 $\mathrm{MHCII}^{+/+} \mathrm{B}$ cells constituted $74.7( \pm 6.1) \%$ of donor GC B cells (Fig. $2 \mathrm{~g}-\mathrm{i}$ ). Over the course of GC response, the advantage of $\mathrm{NP}^{+} \mathrm{MHCII}^{+/+}$ GC B cells remained relatively constant, ranging from $3: 1$ on day 6 , to $2.5: 1$ on day 8 , and $2: 1$ on day 16 (Fig. $2 \mathrm{~g}-\mathrm{i}$ ). Furthermore, the MHCII expression on CD45.2 $\mathrm{MHCII}^{+/-}$and CD45.1 $\mathrm{MHCII}^{+/+} \mathrm{GC} \mathrm{B}$ and $\mathrm{NP}^{+} \mathrm{GC}$ cells maintained the twofold difference between haploinsufficient and WT B cells (Fig. 2j). We conclude that the comparable fitness of WT and haploinsufficient $B$ cells in organized GCs includes the antigen-specific B cells and is not an artifact of "dark antigen" responses ${ }^{22}$.

These short-term reconstitution experiments support the notion that pMHCII density controls B-cell entry and/or proliferation in nascent GCs ${ }^{1}$. Nonetheless, whereas MHCII haploinsufficient B cells are strongly disadvantaged in the earliest stages of the GC response, in organized GCs, $\mathrm{MHCII}^{+/+}$and $\mathrm{MHCII}^{+/-} \mathrm{B}$ cells expressing identical BCR appear to be equally fit.

No increased fitness for $\mathrm{MHCII}^{+/+}$B cells in organized GCs. To rule out the possibility that the stable persistence of MHCII haploinsufficient GC B cells was due to anatomic isolation of $\mathrm{MHCII}^{+/+}$and $\mathrm{MHCII}^{+/-} \mathrm{B}$ cells in different GCs, we generated mixed bone marrow (BM) chimeric mice in which half of the reconstituting cells were from $\mathrm{CD} 45.2^{+} \mathrm{MHCII}^{+/-}$hemizygous 


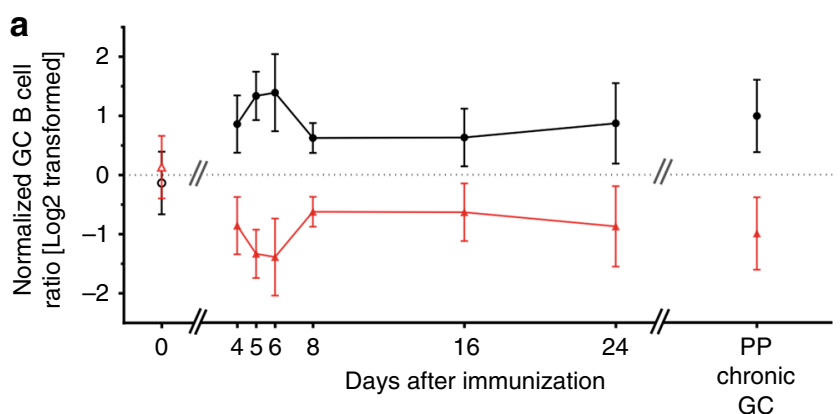

b

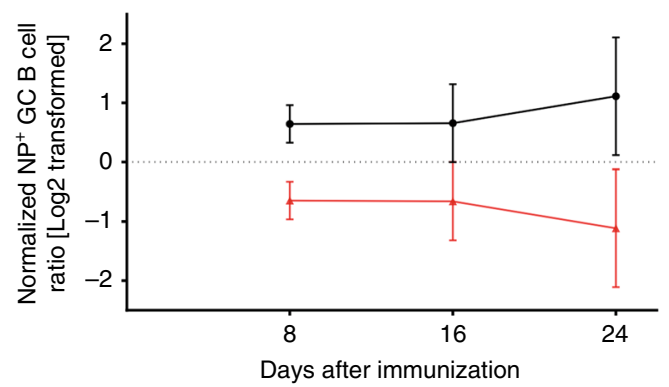

Fig. $4 \mathrm{MHCll}$ haploinsufficient GC B cells have robust competitive fitness in $\mathrm{GCs}$. Kinetics of the proportion of $\mathrm{MHClI}^{+/+}$cells and $\mathrm{MHCll}^{+/-}$cells within a total GC or b NP-binding GC B-cell compartments are shown. To normalize against $\mathrm{B}$-cell chimerism variations in individual recipient animals, donor ratios in day 0 (unimmunized) splenic MF B cells were normalized to the donor ratios in $\mathrm{BM}$ LSK cells $\left(\mathrm{MHCll}^{+/+} / \mathrm{MHCll}^{+/-}\right.$, black hollow circles; $\mathrm{MHCII}^{+/-} / \mathrm{MHCI}^{+/+}$, red hollow triangles). Donor ratios in the GC B cells (days 4-24 spleen and PPs) were normalized to the donor ratios in autologous $\mathrm{MF}$ B cells $\left(\mathrm{MHCll}^{+/+} / \mathrm{MHCll}^{+/}\right.$, black solid circles; $\mathrm{MHClI}^{+/-} / \mathrm{MHClI}^{+/+}$, red solid triangles). Data combined from three independent experiments ( $n=3-15$ for each time point or group); bars indicate mean values $( \pm$ S.D.) of each group

mice and half from CD45.1 $1^{+} \mathrm{MHCII}^{+/+} \mathrm{WT}$ mice. Equal numbers $\left(5 \times 10^{6}\right)$ of $\mathrm{BM}$ cells from both donors were transferred i.v. into sublethally irradiated $(\mathrm{B} 6 . \mathrm{SJL} \times \mathrm{B} 6) \mathrm{F}_{1}\left(\mathrm{CD} 45.1^{+} / \mathrm{CD} 45.2^{+}\right)$congenic recipients (Fig. 3a). Six- to 8 weeks after transfer, the hematopoietic reconstitution of donor origin cells in the myeloid, T-, and B-cell compartments were determined by flow cytometry to ensure chimerism in the lymphoid and myeloid compartments; at this time, virtually all B cells are of donor origin (Supplementary Fig. 4). Reconstituted chimeric animals were immunized i.p. with NP-OVA and the magnitude and dynamics of GC responses were found to match those of B6 control mice (Fig. 3b). On day 6 post immunization, chimeric mice exhibit a small but significant $\left[0.9( \pm 0.5) \%\right.$ of $\mathrm{B} 220^{+} \mathrm{CD}^{-} 3^{-}$cells] population of $\mathrm{GC} \mathrm{B}$ cells (Fig. 3b). By day 8, chimeric mice had GC B-cell frequencies $[3.0( \pm 0.4) \%]$ comparable to those of WT B6 mice (Fig. 1c); the response then waned to $1.6( \pm 0.3) \%$ and $0.5( \pm 0.3) \%$ by days 16 and 24 , respectively (Fig. $3 \mathrm{~b}$ ).

Immunofluorescence labeling of histological sections from spleens at 8- and 16 days after immunization show that $\mathrm{MHCII}^{+/+}$and $\mathrm{MHCII}^{+-}$cells competed in the same GCs (Fig. 3c, e). At both time points, the distributions of

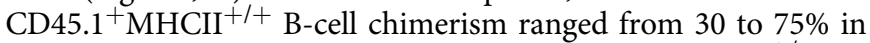
individual GCs; no GCs populated solely by $\mathrm{MHCII}^{+/-}$or $\mathrm{MHCII}^{+/+} \mathrm{B}$ cells were observed (Fig. 3d, f). Based on histologic enumeration, GC B-cell populations were significantly biased for CD45.1 ${ }^{+} \mathrm{MHCII}^{+/+} \mathrm{B}$ cells (Fig. 3d, f), as observed in short-term transfer experiments (Fig. 2). In contrast, adjacent follicular regions were comparably populated by $\mathrm{CD} 45.2^{+} \mathrm{MHCII}^{+/-}$and CD $45.1^{+} \mathrm{MHCII}^{+7+} \mathrm{B}$ cells (Fig. 3d, f). As expected, MHCII and
MHCII-CLIP (class II invariant chain-associated peptide) expression on B cells from both donor genotypes differed twofold in chimeric recipients (Supplementary Fig. 5).

In our short-term transfer studies, diversity in BCR affinity for NP or NIP was minimized by using B1-8 VDJ knock-in donors ${ }^{23}$. To determine whether MHCII haploinsufficient B cells exhibit reduced fitness in GCs when BCR affinity is not constrained, we followed the dynamics of $\mathrm{MHCII}^{+/+}$and $\mathrm{MHCII}^{+/-} \mathrm{B}$ cells responding to immunization with NP-OVA and asked whether MHCII differences have longer term effects in an environment of direct competition. In the large group of chimeric mice studied $(n=56)$, ratios of $\mathrm{MHCII}^{+/+}$and $\mathrm{MHCII}^{+/-} \mathrm{MF}$ splenic B cells varied about a mean of $\cong 2: 3\left[\mathrm{CD} 45.1^{+} \mathrm{MHCII}^{+/+} 37.6( \pm 12.2) \%\right.$ and $\left.\mathrm{CD} 45.2^{+} \mathrm{MHCII}^{+/-} 60.5( \pm 12.4) \%\right]$ that matched the ratio of LSK cells in BM. To normalize against variations in B-cell chimerism, ratios of $\mathrm{MHCII}^{+/+}: \mathrm{MHCII}^{+/-} \mathrm{GC} \mathrm{B}$ cells were normalized to the ratios of $\mathrm{MHCII}^{+/+}: \mathrm{MHCII}^{+/-} \mathrm{MF} \mathrm{B}$ cells in the same animal.

As for short term transfers (Fig. 2), CD45.1 ${ }^{+} \mathrm{MHCII}^{+/+} \mathrm{B}$ cells in chimeric mice exhibited a significant advantage over CD45.2 $2^{+} \mathrm{MHCII}^{+/-} \mathrm{B}$ cells for acquisition of the GC phenotype (Fig. 4). By day 4 post immunization, T-cell-dependent B-cell proliferation and acquisition of the GC phenotype ${ }^{24,25}$ was biased in favor of $\mathrm{MHCII}^{+/+} \mathrm{B}$ cells $\left(\mathrm{MHCII}^{+/+}: \mathrm{MHCII}^{+/-}=\right.$ 1.9:1) (Fig. 4a). This bias for $\mathrm{MHCII}^{+/+}$GC-phenotype B cells grew on days 5 and 6, as GCs form and become organized; by day 8 , ratios of $\mathrm{MHCII}^{+/+}: \mathrm{MHCII}^{+/-}$GC B cells stabilized at $\cong 1.7: 1$, remaining stable on days 16 and -24 even as GC responses waned to $\cong 0.5 \%$ of the MF B-cell compartment (Fig. 4a). Immunization of BM chimeric mice revealed a common pattern of B-cell competition: B cells with higher MHCII densities are strongly advantaged in the earliest stages of the GC response but exhibit no increase in fitness once the GCs become organized. This ratio $(\cong 2: 1)$ of $\mathrm{MHCII}^{+/+}: \mathrm{MHCII}^{+/-} \mathrm{B}$ cells is conserved even in the chronically activated, Peyer's patch GCs of BM chimeric mice (Fig. 4a).

To determine whether the early competitive advantage of $\mathrm{MHCII}^{+/+} \mathrm{B}$ cells included the antigen-specific compartment, we determined the ratios of NP-binding, CD $45.1^{+} \mathrm{MHCII}^{+/+}$and CD 45.2 $2^{+} \mathrm{MHCII}^{+/-}$GC B cells on days 8, 16, and 24 post immunization. Over this period, ratios of $\mathrm{NP}^{+} \mathrm{MHCII}^{+/+}$: $\mathrm{NP}^{+} \mathrm{MHCII}^{+/-} \mathrm{GC} \mathrm{B}$ cells remained relatively constant, ranging from $1.6: 1$ on day 8 , to $1.7: 1$ on day 16 , and $2: 1$ on day 24 (Fig. 4b).

Comparable affinity maturation in $\mathrm{MHCII}^{+/+}$and $\mathrm{MHCII}^{+/-}$ GC B cells. It could be that in competition with WT $\mathrm{MHCII}^{+/+} \mathrm{B}$ cells, haploinsufficient, $\mathrm{MHCII}^{+/-}$GC B cells compensate for diminished pMHCII expression with higher affinity BCRs. Under this model of more stringent selection for $\mathrm{MHCII}^{+/-} \mathrm{GC}$ B cells, average and distributions of BCR affinities would be generally increased in the haploinsufficient GC B-cell compartment. To test this possibility, we used single-cell Nojima cultures to determine AvIn values for GC B cells from mixed- $\left(\mathrm{CD} 45.1^{+} \mathrm{MHCII}^{+/+} / \mathrm{CD} 45.2^{+} \mathrm{MHCII}^{+/-}\right)$and control $\left(\mathrm{CD} 45.1^{+} \mathrm{MHCII}^{+/+} / \mathrm{CD} 45.2^{+} \mathrm{MHCII}^{+/+}\right)$chimeric mice. Both groups of BM chimeras were immunized with NP-OVA, and on days 8,16 , and 24 post immunization we sorted single GC B cells

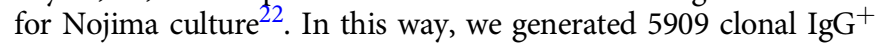
Nojima cultures with cloning efficiencies ranging from 16 to $21 \%$ (Table 1). As before (Fig. 1e), cloning efficiencies and clonal IgG production were comparable between $\mathrm{MHCII}^{+/+}$and $\mathrm{MHCII}^{+/-}$ cells.

AvIns for clonal IgGs from day 8, 16, and 24 GC B cells were determined for high- (permissive) and low density (stringent) 


\begin{tabular}{|c|c|c|c|}
\hline$\underline{B}^{\text {-cell source }}{ }^{a}$ & GC (day 8) & GC (day 16) & GC (day 24) \\
\hline $\begin{array}{l}\mathrm{CD} 45.1^{+} \mathrm{MHCl}^{+/+} \\
\text {lgG }^{+} / \text {total }^{-} \\
\text {screened }^{\mathrm{b}}\end{array}$ & $883 / 4314$ & $1302 / 6520$ & $599 / 3080$ \\
\hline Cloning efficiency & $20.5 \%$ & $20.0 \%$ & $19.5 \%$ \\
\hline $\mathrm{NIP}_{25}{ }^{+}$cultures $^{\mathrm{c}}$ & $220(24.9 \%)$ & $159(11.6 \%)$ & $21(3.5 \%)$ \\
\hline $\mathrm{NIP}_{2}{ }^{+}$cultures $^{\mathrm{c}}$ & $131(14.8 \%)$ & $109(8.4 \%)$ & $15(2.5 \%)$ \\
\hline $\begin{array}{l}\mathrm{NP}_{2}^{+} \text {cultures }^{\mathrm{C}} \\
\mathrm{CD} 45.2^{+} \mathrm{MHCll}^{+/+}\end{array}$ & 57 (6.5\%) & $93(7.2 \%)$ & $12(2.0 \%)$ \\
\hline $\begin{array}{l}\operatorname{lgG}^{+} / \text {total } \\
\text { screened }^{b}\end{array}$ & $705 / 4314$ & $1141 / 6,616$ & $579 / 3080$ \\
\hline Cloning efficiency & $16.3 \%$ & $17.2 \%$ & $18.8 \%$ \\
\hline $\mathrm{NIP}_{25}{ }^{+}$cultures $^{\mathrm{c}}$ & $214(30.3 \%)$ & $180(15.8 \%)$ & $24(4.1 \%)$ \\
\hline $\mathrm{NIP}_{2}{ }^{+}$cultures ${ }^{\mathrm{C}}$ & $152(21.6 \%)$ & $151(13.2 \%)$ & $18(3.1 \%)$ \\
\hline $\mathrm{NP}_{2}+$ cultures $^{\mathrm{C}}$ & $72(10.2 \%)$ & $139(12.2 \%)$ & $20(3.5 \%)$ \\
\hline
\end{tabular}

Splenic GC B cells from BM chimera mice were single-sorted into Nojima cultures for in vitro clonal expansion and plasmacytic differentiation on days 8,16 , and 24 after NP-OVA/Alum immunization. Frequencies and of total- and specific $\lg \mathrm{G}$ in culture supernatants were determined by ELISA and Luminex assays

GC B cells were sorted from either $\mathrm{CD} 45.1^{+} \mathrm{MHClI}^{+/+}$or $\mathrm{CD} 45.2^{+} \mathrm{MHCll}^{+/-}$population at indicated time points

Number of IgG positive samples/number of samples screened

c Number of Ag-binding IgG positive samples

NP- and NIP-binding in comparison to the H33L $\gamma 1$ standard (Fig. 5 and Supplementary Fig. 6). GC B cell populations from day 8 and 16 exhibited affinity maturation as increased geometric mean AvIn values; mean AvIn for $\mathrm{NIP}_{25^{-}}$and $\mathrm{NIP}_{2}$-binding increased 8 - and 19-fold, respectively, between day 8 and day 16 with no evidence for further affinity maturation at day 24 (Fig. 5 and Supplementary Fig. 6). At each sample time point, AvIn distributions and geometric means of clonal IgGs from $\mathrm{MHCII}^{+/+}$and $\mathrm{MHCII}^{+/-}$GC B cells were comparable. From day 8 GC B-cell cultures, $22.7 \%\left(220 / 883\right.$; $\left.\mathrm{MHCII}^{+7+}\right)$ and $30.3 \%$ $\left(214 / 705 ; \mathrm{MHCII}^{+/-}\right)$of clonal IgGs reacted with $\mathrm{NIP}_{25}$-BSA conjugated Luminex beads with both cohorts exhibiting similar AvIn distributions and geometric means ( 0.03 for $\mathrm{MHCII}^{+/+}$vs. 0.05 for $\mathrm{MHCII}^{+/-}$; Fig. 5a and Table 1). As the GC response waned, average AvIn values increased, indicating affinity maturation while fewer clonal IgGs bound $\mathrm{NIP}_{25}$ beads [day 16, $11.6 \% \mathrm{MHCII}^{+/+}(159 / 1302)$ and $15.8 \% \mathrm{MHCII}^{+/-}(180 / 1141)$; day 24, 3.5\% $\mathrm{MHCII}^{+/+}(21 / 599)$ and $4.1 \% \mathrm{MHCII}^{+/+}(24 / 579$; $\left.\mathrm{MHCII}^{+/-}\right)$]. Both WT and haploinsufficient cohorts were characterized by similar AvIn geometric means $(P>0.05$; ANOVA with Friedman test followed by Dunn's multiple comparison post tests) and distributions (Fig. 5a and Table 1). Stringent binding to $\mathrm{NIP}_{2^{-}}$or $\mathrm{NP}_{2}$ conjugated beads was also comparable between the $\mathrm{MHCII}^{+/+}$and $\mathrm{MHCII}^{+/-}$GC B-cell competitors with comparable distributions and geometric means of AvIn at each time point (Fig. 5b, c). Heteroclicity, determined by comparing mean AvIn for $\mathrm{NIP}_{2}$ vs. $\mathrm{NP}_{2}$ beads, was no different between $\mathrm{MHCII}^{+/+}$and $\mathrm{MHCII}^{+/-}$GC B cells (Fig. 5b, c). These patterns of affinity maturation and heteroclicity were virtually identical to that observed in single-cell cultures of $\mathrm{CD}_{4} 5.1^{+} \mathrm{MHCII}^{+/+}$and $\mathrm{CD} 45.2^{+} \mathrm{MHCII}^{+/+} \mathrm{GC} \mathrm{B}$ cells from immunized control chimeric mice (Supplementary Fig. 6). Over the course of primary GC responses, BCR affinities of $\mathrm{MHCII}^{+/-}$ GC B cells match those of their $\mathrm{MHCII}^{+/+}$competitors.

Comparable $\mathrm{V}_{\mathbf{H}}$ mutation in $\mathrm{MHCII}^{+/+}$and $\mathrm{MHCII}^{+/-}$GC B cells. To evaluate the somatic genetics of affinity-driven selection in competing $\mathrm{MHCII}^{+/+}$and $\mathrm{MHCII}^{+/-}$GC B cells, we amplified VDJ rearrangements from $196 \mathrm{IgG}^{+}$Nojima cultures (102
$\mathrm{MHCII}^{+/+}$; $94 \mathrm{MHCII}^{+/-}$) using a multiplex PCR that targets all mouse $\mathrm{V}_{\mathrm{H}}$ gene segments; amplicons were subsequently cloned, sequenced, and annotated ${ }^{22}$. In $60 \mathrm{VDJ}$ rearrangements from MF B cells $\left(\mathrm{MHCII}^{+/+}, n=30 ; \mathrm{MHCII}^{+/-}, n=30\right)$, we observed only a single $\mathrm{V}_{\mathrm{H}}$ mutation ( 1 mutation/15,900 bp sequenced; $\left.6.3 \times 10^{-5}\right)$ (Table 2). In contrast, $\mathrm{V}_{\mathrm{H}}$ mutation frequencies were $\geq 100$-fold higher in GC B cells with $\mathrm{V}_{\mathrm{H}}$ mutation frequencies of $5.6 \times 10^{-3}$ and $4.5 \times 10^{-3}$ for $\mathrm{MHCII}^{+/+}(n=27)$ and $\mathrm{MHCII}^{+1-}(n=25)$ GC B cells on day 8 , and $1.3 \times 10^{-2}$ $\left(\mathrm{MHCII}^{+/+}, n=44\right)$ and $1.5 \times 10^{-2}\left(\mathrm{MHCII}^{+/-}, n=39\right)$ on day 16 (Table 2). Patterns of mutation in both WT and haploinsufficient $\mathrm{B}$ cells was also similar in that $\mathrm{R}: \mathrm{S}$ ratios for $\mathrm{MHCII}^{+/+}$and $\mathrm{MHCII}^{+/-}$GC B cells were comparable: 2.3:1 and $2.0: 1$ on day 8 and $3.9: 1$ to $4.0: 1$ on day 16 (Table 2).

These similarities remained when we restricted our analyses to the canonical $\mathrm{V}_{\mathrm{H}} 1-72$ gene segment that dominates the heteroclitic NP responses of $\mathrm{B} 6$ mice (Table 2). $\mathrm{V}_{\mathrm{H}}$ 1-72 gene segment mutation frequencies and R:S ratios in $\mathrm{MHCII}^{+/+}$and $\mathrm{MHCII}^{+/-}$GC B cells were $4.4 \times 10^{-3}$ and $2.0: 1$, and $5.5 \times 10^{-3}$ and $2.2: 1$ on day 8 with comparable increases $\left(1.5 \times 10^{-2}\right.$ and 5.4:1, and $1.7 \times 10^{-2}$ and 6.7:1, respectively) on day 16 (Table 2). Despite their different capacities for MHCII expression, WT and haploinsufficient GC B cells acquire $\mathrm{V}_{\mathrm{H}}$ mutations in concert and at comparable rates.

\section{Discussion}

BCR affinity maturation in GCs has been proposed to be driven by the quality of $\mathrm{T}_{\mathrm{FH}}$ and GC B-cell interactions, which in turn are determined by pMHCII density on the B-cell surface ${ }^{16}$. To explore this hypothesis quantitatively, we established by B-cell transfer, a venue for competition between congenic B cells that differed by their capacity to express MHCII. B cells hemizygous for MHCII I-A ${ }^{\text {b19 }}$ were haploinsufficient for MHCII expression ${ }^{26}$ regardless of physiologic state (Figs. 1a, 2j and Supplementary Fig. 5). The haploinsufficiency extended to pMHCII as well; NPbinding B cells from $\mathrm{MHCII}^{+/-}$mice immunized with NP-SA-Ea expressed half the level of Ea peptide/MHCII complex of $\mathrm{MHCII}^{+/+}$controls (Fig. 1b and Supplementary Fig. 3). This quantitative model allows us to explore the role of pMHCII density in clonal selection in humoral immune responses.

$\mathrm{MHCII}^{+/-}$mice mounted serum IgG and GC responses to NP-OVA that were indistinguishable from those of B6 controls (Fig. 1d). This identity shows that pMHCII density per se does not determine the magnitude of humoral responses and recalls the observation that GC responses in $\mathrm{B} 1-8^{\text {hi }}$ and B1-8 ${ }^{\text {lo }}$ mice exhibit comparable kinetics despite great differences (40-fold) in BCR affinity for $\mathrm{NP}^{23}$. However, when $\mathrm{MHCII}^{+/+}$ and $\mathrm{MHCII}^{+/-} \mathrm{B}$ cells directly compete after immunization, $\mathrm{MHCII}^{+/+} \mathrm{B}$ cells exhibit a significant advantage over $\mathrm{MHCII}^{+/-}$ competitors in populating nascent GCs (Fig. 2d-f). This early advantage is not associated with differences in antigen binding, as it persists even when BCR affinities between the competing B cells are homogenized by a shared VDJ knock-in (Fig. 2d-f). This early advantage of $\mathrm{MHCII}^{+/+} \mathrm{B}$ cells follows $\mathrm{B}$-cell activation, as the appearance and numbers of $\mathrm{IgD}^{\text {low }} \mathrm{NP}^{+} \mathrm{B}$ cells following immunization with NP immunogens is identical for $\mathrm{MHCII}^{+/}$ and $\mathrm{MHCII}^{+/-} \mathrm{B}$ cells (Supplementary Fig. 3). We conclude that the early advantage of $\mathrm{MHCII}^{+/+} \mathrm{B}$ cells reflects pMHCIIdependent selection at the initial, $\mathrm{T}_{\mathrm{H}^{-}}$-dependent entry of antigenactivated $\mathrm{B}$ cells into humoral responses ${ }^{1,27}$.

To our surprise, the early competitive advantage for $\mathrm{MHCII}^{+/+} \mathrm{B}$ cells was lost once GCs became organized (Figs. 2f and $4 \mathrm{a})$. The skewed ratios of $\mathrm{MHCII}^{+/+}$and $\mathrm{MHCII}^{+/-} \mathrm{B}$ cells entering GCs become stable and persist without significant change once GC organization is established (Figs. 2f and 4a). 
a

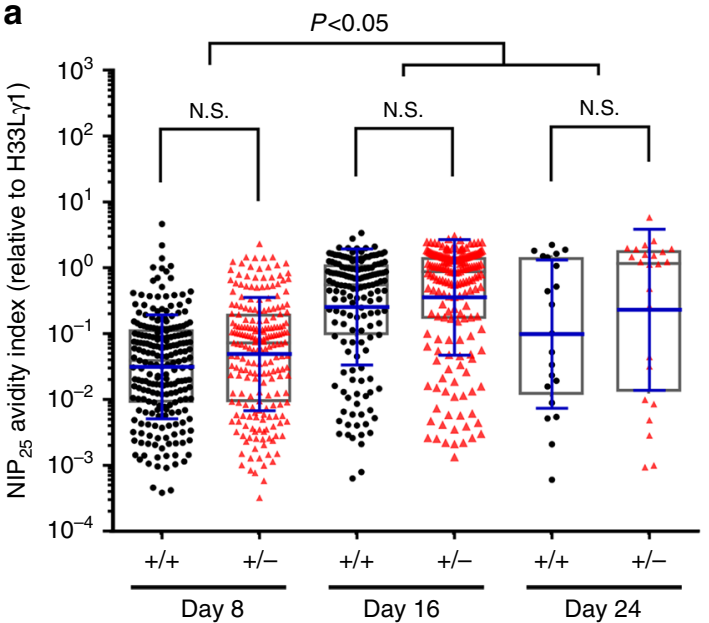

C

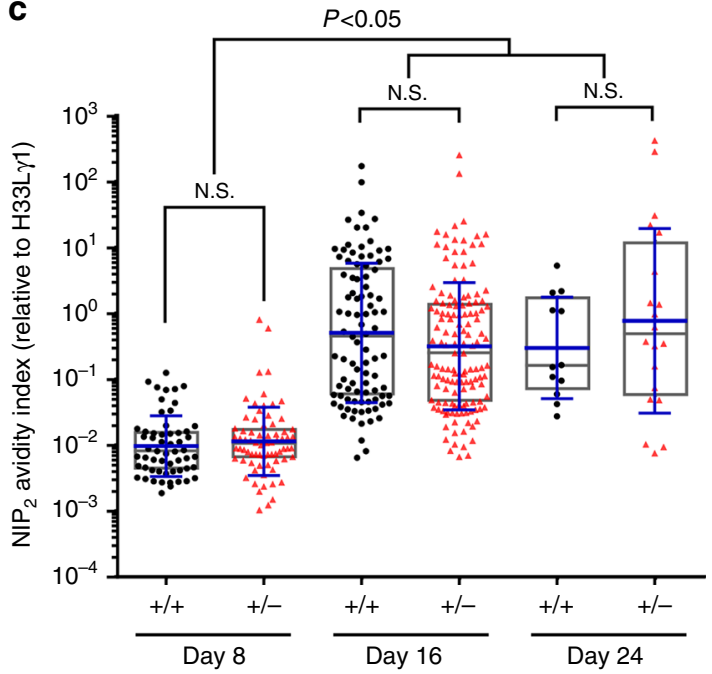

b

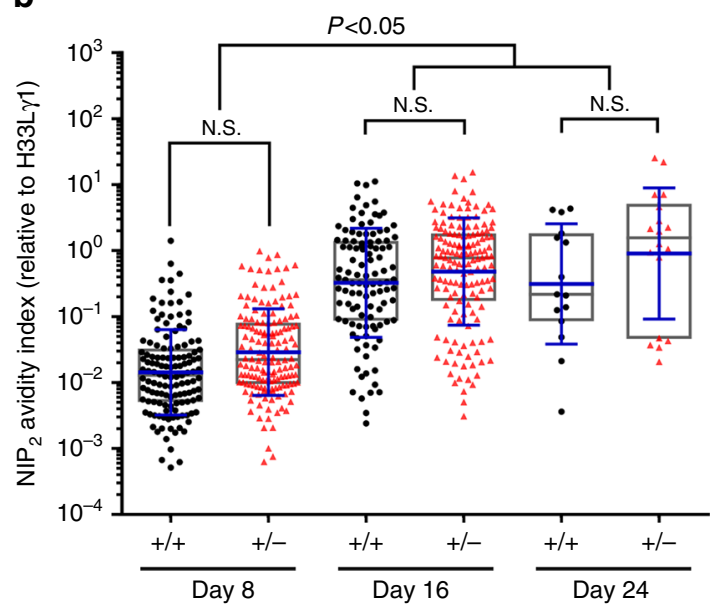

- $\mathrm{MHClI}^{+++}$

$\triangle \mathrm{MHCl}^{+/-}$

Fig. 5 Competing $\mathrm{MHCll}^{+/+}$and $\mathrm{MHClI}^{+/-}$B cells show identical affinity maturation. Single-cell, Nojima cultures were established from splenic GC B cells isolated from $\mathrm{BM}$ chimeric mice at days 8, 16, and 24 post immunization (Fig. 3a). a $\mathrm{NIP}_{25^{-}}$, b $\mathrm{NIP}_{2^{-}}$, and $\mathbf{c} \mathrm{NP}_{2}$-specific Avln values (relative to the $\mathrm{H} 33 \mathrm{~L} \gamma 1$ standard) are shown. Each symbol $\left(\mathrm{MHClI}^{+/+}\right.$, black circles; $\mathrm{MHClI}^{+/-}$, triangles) represents the Avln value of one IgG ${ }^{+}$clonal culture sample $(n=12-220$, Table 1). Boxes represent the 25th, 75th percentiles and median. Bars (blue) indicate the geometric mean and \pm S.D. Statistical significance $(P<0.05)$ was measured using two-way ANOVA with Friedman test followed by Dunn's multiple comparison post tests. N.S. not significant

Stability in the ratios of $\mathrm{MHCII}^{+/+}: \mathrm{MHCII}^{+/-}$GC B cells did not reflect anatomical segregation as histologic studies confirmed that all GCs were populated by both $\mathrm{MHCII}^{+/+}$and $\mathrm{MHCII}^{+/-} \mathrm{B}$ cells (Fig. 3c-f). In GCs, B cells with twofold differences in MHCII expression exhibit the same capacity for persistence within LZ and DZ GC pools. If affinity-dependent competition among GC B cells essentially reflects the "mapping" of BCR affinity onto pMHCII density, our experiments indicate that while MHCII density and T-cell help are limiting factors in preGC selection, in established GCs this selection is less stringent. This relaxation of pMHCII selection intensity may support the "permissive" affinity-dependent selection noted for complex protein antigens in established $\mathrm{GCs}^{22}$.

Selection on complex phenotypes often results in compensation. For example, mice deficient in CD21/CD35 exhibit reduced serum IgG responses but enhanced affinity maturation ${ }^{28}$ and mixed chimera mice with normal and $\mathrm{ICOSL}^{-1-} \mathrm{B}$ cells show affinity compensation in $\mathrm{ICOSL}^{-1-} \mathrm{GC}$ B cells and plasmacytes $^{29}$. To exclude the possibility that $\mathrm{MHCII}^{+/-}$GC B cells compensate for lower pMHCII densities by increased BCR affinity, we determined the BCR AvIns for $\approx 800$ individual MHCII $+/+$ and $\mathrm{MHCII}^{+/-}$GC B cells to NP and NIP (Fig. 5).
Heteroclitic, affinity maturation was highly similar between $\mathrm{MHCII}^{+/+}$and $\mathrm{MHCII}^{+/-}$GC B cells, with no compensatory affinity increases observed in $\mathrm{MHCII}^{+/}$GC B cells (Fig. 5 and Supplementary Fig. 6). Mean AvIn values did not differ significantly between $\mathrm{MHCII}^{+/+}$and $\mathrm{MHCII}^{+/-}$GC B cells at any sample time and AvIn distributions were comparable in each cohort (Fig. 5). Direct measurement of BCR avidity obviates the limitations of predicting affinity maturation by enumerating affinity-enhancing mutations ${ }^{29}$.

Immunofluorescence studies of immunized chimeric mice showed that all GCs comprised B cells from both $\mathrm{MHCII}^{+/+}$and $\mathrm{MHCII}^{+/-}$donors, demonstrating that these B cells competed in common GC niches (Fig. 3c-h). That both groups exhibited similar AvIn distributions, including comparable lower avidity "tail" populations (Fig. 5) 22,30 , ensures that spatial segregation cannot account for persistence and continuing affinity maturation of $\mathrm{MHCII}^{+/-} \mathrm{GC} \mathrm{B}$ cells.

We find it highly unlikely that pMHCII on $\mathrm{MHCII}^{+/+}$and $\mathrm{MHCII}^{+/-}$GC B cells are ever equalized. Bannard et al. have reported that MHCII molecules turn over rapidly in DZ B cells by ubiquitin-mediated degradation ${ }^{31}$, perhaps to ensure that pMHCII density accurately represents BCR affinity. If so, 
Table $2 V_{H}$ gene sequence summary of single B-cell Nojima cultures

\begin{tabular}{|c|c|c|c|c|c|}
\hline \multicolumn{2}{|l|}{ B-cell source ${ }^{a}$} & MF (day 8) & GC (day 8) & MF (day 16) & GC (day 16) \\
\hline \multicolumn{6}{|c|}{$\mathrm{CD}^{2} 5.1^{+} \mathrm{MHCl}+/+$} \\
\hline \multirow[t]{5}{*}{ Total } & Clone sequenced ${ }^{b}$ & 15 & 27 & 15 & 44 \\
\hline & Total base pair sequenced & 3981 & 7161 & 3972 & 11,660 \\
\hline & Mutation number & 0 & 40 & 0 & 147 \\
\hline & Mutation frequency ${ }^{\mathrm{C}}$ & $N / A$ & $5.59 \times 10^{-3}$ & $N / A$ & $1.26 \times 10^{-2}$ \\
\hline & $\mathrm{R} / \mathrm{S}$ ratio $^{\mathrm{d}}$ & $\mathrm{N} / \mathrm{A}$ & $2.33(28 / 12)$ & $N / A$ & $3.90(117 / 30)$ \\
\hline \multirow[t]{5}{*}{$V_{H} 1-72^{e}$} & Clone sequenced $^{\mathrm{b}}$ & 0 & 13 & 1 & 11 \\
\hline & Total base pair sequenced & 0 & 3445 & 265 & 2915 \\
\hline & Mutation number & 0 & 15 & 0 & 45 \\
\hline & Mutation frequency ${ }^{c}$ & $\mathrm{~N} / \mathrm{A}$ & $4.35 \times 10^{-3}$ & $\mathrm{~N} / \mathrm{A}$ & $1.54 \times 10^{-2}$ \\
\hline & $\mathrm{R} / \mathrm{S}$ ratio ${ }^{\mathrm{d}}$ & $\mathrm{N} / \mathrm{A}$ & $2.00(10 / 5)$ & $\mathrm{N} / \mathrm{A}$ & $5.43(38 / 7)$ \\
\hline \multicolumn{6}{|c|}{$\mathrm{CD} 45.2^{+} \mathrm{MHCl}^{+/+}$} \\
\hline \multirow[t]{5}{*}{ Total } & Clone sequenced ${ }^{b}$ & 15 & 25 & 15 & 39 \\
\hline & Total base pair sequenced & 3975 & 6631 & 3972 & 10,341 \\
\hline & Mutation number & & 30 & 0 & 154 \\
\hline & Mutation frequency ${ }^{\mathrm{C}}$ & $2.51 \times 10^{-4}$ & $4.52 \times 10^{-3}$ & $\mathrm{~N} / \mathrm{A}$ & $1.49 \times 10^{-2}$ \\
\hline & $\mathrm{R} / \mathrm{S}$ ratio $^{\mathrm{d}}$ & $N / A$ & $2.00(20 / 10)$ & $\mathrm{N} / \mathrm{A}$ & $3.97(123 / 31)$ \\
\hline \multirow[t]{5}{*}{$V_{H^{1-72}}$} & Clone sequenced $^{b}$ & 0 & 11 & 2 & 15 \\
\hline & Total base pair sequenced & 0 & 2915 & 530 & 3975 \\
\hline & Mutation number & 0 & 16 & 0 & 69 \\
\hline & Mutation frequency ${ }^{c}$ & $N / A$ & $5.49 \times 10^{-3}$ & $\mathrm{~N} / \mathrm{A}$ & $1.73 \times 10^{-2}$ \\
\hline & $\mathrm{R} / \mathrm{S}$ ratio ${ }^{d}$ & $\mathrm{~N} / \mathrm{A}$ & $2.20(11 / 5)$ & $\mathrm{N} / \mathrm{A}$ & $6.67(60 / 9)$ \\
\hline \multicolumn{6}{|c|}{$\begin{array}{l}\mathrm{V}(\mathrm{D}) \mathrm{J} \text { rearrangements of cultured } \mathrm{B} \text { cells were amplified by a nested } \\
\text { www.imgt.org/) } \\
\text { a } \mathrm{GC} \mathrm{B} \text { cells were sorted from either } \mathrm{CD} 45.1^{+} \mathrm{MHClI}^{+/+} \text {or } \mathrm{CD} 45 \\
\text { b Number of IgG } \mathrm{G}^{+} \text {Nojima cultures subjected to } \mathrm{VDJ} \text { sequencing } \\
\text { c Total mutation numbers/total base pair sequenced } \\
\text { d Ratio of replacement/silent mutations } \\
\text { e } \mathrm{B} \text { cell clones carrying } \mathrm{V}_{\mathrm{H}} \mathrm{T}-72 \text { rearrangement }\end{array}$} \\
\hline
\end{tabular}

pMHCII densities on WT and haploinsufficient B cells would reflect the abundance of the immediate precursor, the MHCIICLIP complex, which is halved also in $\mathrm{MHCII}^{+/-}$GC B cells (Supplementary Fig. 5).

The notion that GC B cells with higher pMHCII densities are advantaged in GCs by enhanced $\mathrm{T}_{\mathrm{FH}}$ help came from experiments in which antigen linked to DEC-205 mAb (aDEC-205-Ag) was delivered to DEC-205 ${ }^{+}$GC B cells ${ }^{5}$, 9 . This targeted loading of antigen is $\mathrm{BCR}$ and FDC independent but correlated with increased $\mathrm{B}: \mathrm{T}_{\mathrm{FH}}$ interaction, $\mathrm{DZ}$ proliferation, and $\mathrm{V}_{\mathrm{H}}$ mutation frequencies 9,15 . We see no evidence for these effects when competing B cells acquire antigen via their BCR. What is surprising is that B-cell entry into GC responses is strongly affected by a twofold reduction in MHCII and pMHCII (Figs. 2 and 4). If the GC represents the paradigm for affinity-dependent, B-cell selection, it seems counter-intuitive that $\mathrm{T}: \mathrm{B}$ interactions that initiate humoral responses are more stringent than those within the GC.

Results from other experimental models that establish competition between B cells with higher- or lower levels of MHCII expression are similar to our own. For example, in the absence of $\mathrm{H} 2-\mathrm{O}$ expression, $\mathrm{B}$ cells with elevated pMHCII densities exhibit a pronounced advantage over WT B cells on entry into GCs, but once GCs become established ratios of $\mathrm{H} 2-\mathrm{O}$-deficient and -sufficient GC B cells remain constant for 21 days $^{32}$. Likewise, Bannard et al. infected mixed BM chimeric mice containing B cells that expressed normal MHCII or MHCII resistant to ubiquitination mediated turnover with influenza ${ }^{31}$. One week after infection, ubiquitin resistant GC B cells represented $10-50 \%$ of GC B cells while at 5 weeks these cells remained almost as abundant at $0-40 \%{ }^{31}$. Finally, immunization of mixed BM chimeric mice containing WT and $\mathrm{CD}^{-1-} \mathrm{B}$ cells (with lower MHCII expression) with SRBC resulted in an early preference for CD83-sufficient GC B cells, but with little or no change in

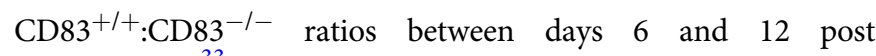
immunization $^{33}$.

The permissive nature of selection in $\mathrm{GCs}^{22}$ was recently underscored when Turner et al. showed that B cells responding to a dissimilar antigen could enter into and persist within an ongoing GC response ${ }^{34,35}$. These authors show that HyHEL-10 B cells specific for hen- (HEL) and duck egg lysozyme (DEL) exposed ex vivo to DEL-OVA enter and proliferate in GCs elicited by DELOVA or OVA immunization with equal efficiency ${ }^{35}$. One surprising interpretation of this result is that the B cell's initial exposure to antigen determines its fitness for the GC response rather than the ability to recover antigen repeatedly from GC FDCs. If these results $^{34,35}$ are generalizable, current models for affinity-dependent selection in GCs require substantial revision. At least one possibility is that in the LZ, low affinity GC B cells have a substantial chance of receiving "bystander help" from local $\mathrm{T}_{\mathrm{FH}}$ activated by fitter cells. Such unspecific help would be consistent with recent results from the Nussenzweig laboratory ${ }^{36}$ showing that apoptosis in the GC LZ is essentially independent of BCR affinity.

The GC is a dynamic microenvironment where antigenactivated B cells iteratively undergo proliferation, hypermutation, and affinity-driven selection. By direct observation, selection for higher BCR affinities in GCs is rapid and relies on the unequal success of mutant B cells in generating progeny. Nonetheless, GC B-cell populations also comprise substantial subsets of mutated B cells with very low BCR avidities and GC selection may be functionally permissive for these less fit populations ${ }^{22,30}$. Given that pathogens evolve under selection by host immunity, permissive selection may be a strategy to optimize memory B-cell compartments against pathogen variants that have escaped immune control. The development of broadly neutralizing antibodies to influenza and HIV from B-cell clonal lineages characterized by extraordinary frequencies of $\mathrm{V}(\mathrm{D}) \mathrm{J}$ mutation are consistent with this tortuous pathway to protective efficacy ${ }^{37-40}$. 
In summary, by allowing congenic $\mathrm{MHCII}^{+/+}$and $\mathrm{MHCII}^{+/-}$ $\mathrm{B}$ cells to compete directly, we show that WT and haploinsufficient GC B cells exhibit similar fitness in GCs as determined by their proliferation, persistence, mutation frequencies, and affinity maturation. In contrast, haploinsufficient B cells are significantly disadvantaged during the initiation of humoral responses, most likely during the initial $\mathrm{T}: \mathrm{B}$ collaboration that marks the start of humoral responses. If affinity-driven selection is determined by pMHCII density on B cells, that mechanism appears to be significantly more stringent at the initiation of the humoral response than during the GC reaction itself.

\begin{abstract}
Methods
Mice and immunizations. C57BL/6, B6.SJL-Ptprc ${ }^{\mathrm{a}} \mathrm{Pepc}^{\mathrm{b}} / \mathrm{BoyJ}\left(\mathrm{CD} 45.1^{+/+}\right)$, B6.129S2-H2 $2^{\mathrm{dlAb} 1-\mathrm{Ea} / J}\left(\mathrm{MHCII}^{-/-}\right)$, and B6.129P2 (C) $-\mathrm{Ightm}^{\mathrm{Cgn}} / \mathrm{J}\left({\left.\mathrm{B} 1-8 \mathrm{i}^{+/+}\right)}^{+}\right.$ female mice were purchased from the Jackson Laboratory and were maintained under specific pathogen-free, temperature- and humidity-controlled conditions at the Duke University Animal Care Facility and used in experiments at 8-12 weeks of age. Due to the limited availability of knockout and chimeric mice, no randomization was used. The investigator was not blinded to the group allocation during the animal experiments. Sample size to ensure adequate statistical power was based on prior experience in the laboratory. Mice were immunized i.p. with $20 \mu \mathrm{g}$ of $\mathrm{NP}_{15}$-OVA/Alhydrogel adjuvant $2 \%(1: 1, \mathrm{v} / \mathrm{v})$ (Biosearch Technologies and InvivoGen) in a final volume of $200 \mu \mathrm{L}$. Serum and spleen samples were collect on days 4-24 after immunization. All experiment procedures involving animals were approved by the Duke University Institutional Animal Care and Use Committee.
\end{abstract}

Short-term transfer and mixed bone marrow chimeric mice. For short-term cell transfers, single-cell suspensions were harvested and processed from spleens of B1$8^{+/+} \mathrm{MHCII}^{++}\left(\mathrm{CD} 45.1^{+}\right)$and $\mathrm{B} 1-8^{+/+} \mathrm{MHCII}^{+/-}\left(\mathrm{CD} 45.2^{+}\right)$or B1-8 $8^{+/+} \mathrm{MHCII}$ $+/+\left(\mathrm{CD} 45.2^{+}\right)$mice. Splenocytes were stained with biotinylated-Abs $(\alpha \mathrm{CD} 4$, $\alpha \mathrm{CD} 11 \mathrm{c}, \alpha \mathrm{CD} 43, \alpha \mathrm{CD} 90.2, \alpha \mathrm{F} 4 / 80$, and $\alpha \mathrm{GL}-1)$ and subsequently labeled with Streptavidin MicroBeads (Miltenyi Biotec). B cells were then negatively purified using magnetic activated cell sorting with CS column on a VarioMACS separator (Miltenyi Biotec). After sorting, purified B cell samples were stained and examined using flow cytometry to determine the purity and percentage of $\mathrm{NP}^{+}$populations. $100 \mu \mathrm{L}$ of cell mixtures containing $2 \times 10^{6}$ cells with $1: 1$ ratios of $\mathrm{NP}^{+} \mathrm{CD} 45.1$ ${ }^{+/+} \mathrm{B} 1-8^{+/+} \mathrm{MHCII}^{+/+}$and $\mathrm{NP}^{+} \mathrm{CD} 45.2^{+/+} \mathrm{B} 1-8^{+/+} \mathrm{MHCII}^{+/-} \mathrm{B}$ cells were transferred i.v. to individual recipient $(\mathrm{B} 6 . \mathrm{SJL} \times \mathrm{B} 6) \mathrm{F}_{1}\left(\mathrm{CD} 45.1^{+} / \mathrm{CD} 45.2^{+}\right)$mice. To generate mixed BM chimeric mice, $(\mathrm{B} 6 . \mathrm{SJL} \times \mathrm{B} 6) \mathrm{F}_{1}\left(\mathrm{CD} 45.1^{+} / \mathrm{CD} 45.2^{+}\right)$mice were sub-lethally irradiated with a single dose of $6.5 \mathrm{~Gy} \mathrm{X}$-ray and then injected i.v. with equal numbers $\left(2.5 \times 10^{6}\right.$ cells $)$ of BM cells harvested from B6.SJL $\left(\mathrm{CD} 45.1^{+}\right)$ and $\mathrm{MHCII}^{+1-}\left(\mathrm{CD} 45.2^{+}\right)$or B6 $\left(\mathrm{CD} 45.2^{+}\right)$mice. Reconstituted mice were rested for 6-8 weeks before use in experiments.

Antibodies and flow cytometry. For surface marker detection, samples were resuspended in PBS containing $0.5 \%$ bovine serum albumin, $0.1 \%$ sodium azide and $1 \mathrm{mM}$ EDTA (FACS buffer). Resuspended cells were blocked with rat antimouse CD16/32 (2.4G2) and rat IgG (Sigma-Aldrich) in FACS buffer for $30 \mathrm{~min}$ and stained with fluorochrome-conjugated antibodies specific for CD19 (1D3), CD21/35 (7E9), CD23 (B3B4), CD38 (90), CD43 (S7), CD45.1 (A20), CD45.2 (104), CD86 (GL-1), CD93 (AA4.1), CD95 (Fas; Jo2), CD138 (281-2), CD184 (CXCR4; L276F12), B220 (RA3-6B2), GL-7 (GL7), I-A/I-E (M5/114.15.2), I-Ab (AF6-120.1), IgD (11-26 c.2a), IgM (II/41) and MHC-Clip (15G4) or NP 14 -PE chemical (Biosearch Technologies) at $4^{\circ} \mathrm{C}$ for 30-40 $\mathrm{min}$ (Supplementary Table 1). LIVE/DEAD Fixable Near-IR Dead Cell Stain Kit (Life Technologies) was used to determine the viability of cells. Subsequently, cells were washed twice with FACS buffer, and the resuspended cells were then analyzed on LSRII or LSRFortessa cell analyzer (BD Biosciences). Fluorescence activated cell sorting was acquired on MoFLo Astrios sorter (Beckman Coulter), FACSVantage SE sorter with DIVA Option or FACSAria sorter (BD Biosciences). The data analysis was performed using FACSDiva (BD Biosciences) and FlowJo software (Tree Star). Specific cell population and gating strategy are described in Supplementary Fig. 2.

Single B-cell culture. Single MF and GC B cells from control mice and immunized mice were expanded in the presence of NB-21.2D9 feeder cells (Nojima cultures) as described $^{22}$. Briefly, NB-21.2D9 feeder cells (2000 cells/well) were pre-seeded into 96 well culture plate with RPMI 1640 media (Life Technologies) supplemented with 10\% FBS (Thermo Fisher Scientific), $10 \mathrm{mM}$ HEPES, $1 \mathrm{mM}$ sodium pyruvate, $1 \times$ MEM nonessential amino acid, $100 \mathrm{U} / \mathrm{mL}$ penicillin-streptomycin and $5.5 \times 10$

${ }^{-5}$ M 2-mercaptoethanol (All Life Technologies). Next day, single MF and GC B cells were directly sorted into NB-21.2D9 culture plates and cultured in the presence of exogenous recombinant IL-4 (2 ng/ml, Peprotech) and CD154/BAFF/IL21-expressing NB-21.2D9 cells. Two-thirds of culture media were replaced with fresh media daily from days 2 to -8 . On day 10 , culture supernatants and cell pellets were harvested for subsequent ELISA IgG determinations and V(D)J amplifications, respectively.

ELISA and luminex multiplex immunoassays. Concentrations of IgG in harvested culture supernatants were determined by standard sandwich ELISA as described $^{22}$. Briefly, 384-well ELISA plates (Corning) were coated with anti-mouse Igk $\mathrm{Ab}$ and anti-mouse $\operatorname{Ig} \lambda \mathrm{Ab}(2 \mu \mathrm{g} / \mathrm{ml}$ each; Southern Biotech $)$ in carbonate buffer overnight at $4{ }^{\circ} \mathrm{C}$. After blocking with PBS containing $0.5 \% \mathrm{BSA}$ for $1 \mathrm{~h}$ at room temperature, serially diluted samples (1:100, 1:1000, and 1:2000 dilutions) or the $\mathrm{H} 33 \mathrm{~L} \gamma 1 \mathrm{mAb}$ standard were applied to the plate and incubated overnight at $4{ }^{\circ} \mathrm{C}$. After washing, HRP-conjugated anti-mouse IgG (1:5000 dilution; Southern Biotech) was added and incubated at room temperature for $1 \mathrm{~h}$. After washing, bound HRP activity was visualized using a TMB peroxidase kit (BioLegend) and the optical densities (O.D.) were determined at $450 \mathrm{~nm}$ with a SpectraMax M2 Microplate Reader (Molecular Devices). IgG ${ }^{+}$supernatants screened by ELISA and serum samples were subjected to Luminex Multiplex Immunoassay for the detection of avidity against different antigen as reported ${ }^{41}$. Briefly, $1 \times 10^{7}$ coded MicroPlex microspheres (Luminex) were covalently linked to $50 \mu \mathrm{g}$ of $\mathrm{NP}_{2}-\mathrm{BSA}$, $\mathrm{NP}_{30}$-BSA, NIP 2 -BSA, NIP ${ }_{25}$-BSA (Biosearch Technologies), OVA (SigmaAldrich), Igא, Ig $\lambda$, or IgG (Southern Biotech), respectively. Conjugated microsphere mixture were incubated with diluted samples for $2 \mathrm{~h}$ at room temperature. After washing, any IgG Ab bound to the microspheres was detected with $2 \mu \mathrm{g} / \mathrm{ml}$ PE goat anti-mouse IgG (Southern Biotech). Fluorescence was measured on a Bio-Plex 3D suspension array system (Bio-Rad Laboratories).

Immunohistochemistry. Harvested spleens were embedded in Tissue-Tek OCT Compound (Sakura Finetek) and frozen at $-80^{\circ} \mathrm{C} .5-10 \mu \mathrm{m}$-thick sections were mounted on glass slides and rehydrated by soaking in wash solution (PBS containing $0.5 \%$ BSA and $0.1 \%$ Tween 20 ) at RT for $30 \mathrm{~min}$. Samples were then blocked with rat anti-mouse CD16/CD32 (90) and rat IgG (Sigma-Aldrich) for 15 min at room temperature. After washing, the samples were incubated with CD4 (GK1.5), CD45.1 (A20), CD45.2 (104), GL-7 (GL7), and IgD (11-26c.2a) in a humid, dark chamber for $3 \mathrm{~h}$ at RT or $4^{\circ} \mathrm{C}$ overnight (Supplementary Table 1). After washing, the samples were then incubated with secondary or enhancing antibodies for $1 \mathrm{~h}$ at RT. Images were acquired by confocal microscopy using a Zeiss LSM 780 confocal microscope (Zeiss; $\times 200$ magnification). CD45.1 and CD45.2 positive B cells in GC or B-cell follicle area were quantified using Image software (National Institutes of Health).

BCR repertoire analysis and Ig SHM. V(D)J rearrangements of cultured B cells were amplified by a nested PCR as described ${ }^{22}$. Briefly, total RNA was extracted from selected culture cell pellets using TRIzol or TRIzol LS reagents (Invitrogen) and cDNA was subsequently synthesized using Superscript III with oligo $(\mathrm{dT})_{20}$ primers. The cDNA were then subjected to two rounds of PCR with established primers ${ }^{42,}{ }^{43}$. V(D)J amplicons were gel purified, ligated into vectors, and transformed into bacteria for further sequencing. DNA sequencing were performed at Duke DNA sequencing facility. The rearranged $\mathrm{V}, \mathrm{D}$, and $\mathrm{J}$ gene segments and mutation numbers were identified using IMGT/V-QUEST (http://www.imgt.org/) The replacement/silent mutation $(\mathrm{R} / \mathrm{S})$ ratio were calculated based on the sequenced $\mathrm{V}_{\mathrm{H}}$ exon region (FR1 to the start of CDR3)

Statistical analysis. Statistical comparisons were determined using two-tailed Student's $t$ test with Mann-Whitney's $U$ test or analysis of variance (ANOVA) with Kruskal-Wallis test (one-way) or Friedman test (two-way) followed by Dunn's multiple comparison post tests. Differences were considered statistically significant when the $P$ values $<0.05$

Data availability. Sequence data that support the findings of this study have been deposited in GenBank with the accession codes MF942137-MF942331.

Received: 30 October 2017 Accepted: 8 February 2018

Published online: 02 March 2018

\section{References}

1. Schwickert, T. A. et al. A dynamic T cell-limited checkpoint regulates affinitydependent B cell entry into the germinal center. J. Exp. Med. 208, 1243-1252 (2011).

2. Dal Porto, J. M., Haberman, A. M., Kelsoe, G. \& Shlomchik, M. J. Very low affinity B cells form germinal centers, become memory B cells, and participate in secondary immune responses when higher affinity competition is reduced. J. Exp. Med. 195, 1215-1221 (2002).

3. Shih, T. A., Roederer, M. \& Nussenzweig, M. C. Role of antigen receptor affinity in T cell-independent antibody responses in vivo. Nat. Immunol. 3, 399-406 (2002) 
4. Victora, G. D. \& Nussenzweig, M. C. Germinal centers. Annu. Rev. Immunol. 30, 429-457 (2012).

5. Victora, G. D. et al. Germinal center dynamics revealed by multiphoton microscopy using a photoactivatable fluorescent reporter. Cell 143, 592-605 (2010).

6. Allen, C. D., Okada, T., Tang, H. L. \& Cyster, J. G. Imaging of germinal center selection events during affinity maturation. Science 315, 528-531 (2007).

7. Jacob, J., Kelsoe, G., Rajewsky, K. \& Weiss, U. Intraclonal generation of antibody mutants in germinal centres. Nature 354, 389-392 (1991).

8. Jacob, J., Przylepa, J., Miller, C. \& Kelsoe, G. In situ studies of the primary immune response to (4-hydroxy-3- nitrophenyl)acetyl. III. The kinetics of $\mathrm{V}$ region mutation and selection in germinal center B cells. J. Exp. Med. 178, 1293-1307 (1993).

9. Gitlin, A. D., Shulman, Z. \& Nussenzweig, M. C. Clonal selection in the germinal centre by regulated proliferation and hypermutation. Nature 509, 637-640 (2014).

10. Kepler, T. B. \& Perelson, A. S. Cyclic re-entry of germinal center B cells and the efficiency of affinity maturation. Immunol. Today 14, 412-415 (1993).

11. Figge, M. T. et al. Deriving a germinal center lymphocyte migration model from two-photon data. J. Exp. Med. 205, 3019-3029 (2008).

12. Radmacher, M. D., Kelsoe, G. \& Kepler, T. B. Predicted and inferred waiting times for key mutations in the germinal centre reaction: evidence for stochasticity in selection. Immunol. Cell Biol. 76, 373-381 (1998).

13. Batista, F. D. \& Neuberger, M. S. Affinity dependence of the B cell response to antigen: a threshold, a ceiling, and the importance of off-rate. Immunity $\mathbf{8}$ 751-759 (1998).

14. Crotty, S. Follicular helper CD4 T cells (TFH). Annu. Rev. Immunol. 29 621-663 (2011).

15. Gitlin, A. D. et al. HUMORAL IMMUNITY. T cell help controls the speed of the cell cycle in germinal center B cells. Science 349, 643-646 (2015).

16. Shulman, $Z$. et al. Dynamic signaling by $\mathrm{T}$ follicular helper cells during germinal center B cell selection. Science 345, 1058-1062 (2014).

17. Han, S. et al. Cellular interaction in germinal centers. Roles of CD40 ligand and B7-2 in established germinal centers. J. Immunol. 155, 556-567 (1995)

18. $\mathrm{Xu}, \mathrm{H}$. et al. Follicular T-helper cell recruitment governed by bystander B cells and ICOS-driven motility. Nature 496, 523-527 (2013).

19. Madsen, L. et al. Mice lacking all conventional MHC class II genes. Proc. Natl Acad. Sci. USA 96, 10338-10343 (1999).

20. Rudensky, A., Rath, S., Preston-Hurlburt, P., Murphy, D. B. \& Janeway, C. A. Jr. On the complexity of self. Nature 353, 660-662 (1991).

21. Dal Porto, J. M., Haberman, A. M., Shlomchik, M. J. \& Kelsoe, G. Antigen drives very low affinity B cells to become plasmacytes and enter germinal centers. J. Immunol. 161, 5373-5381 (1998).

22. Kuraoka, M. et al. Complex antigens drive permissive clonal selection in germinal centers. Immunity 44, 542-552 (2016).

23. Shih, T. A., Meffre, E., Roederer, M. \& Nussenzweig, M. C. Role of BCR affinity in $\mathrm{T}$ cell dependent antibody responses in vivo. Nat. Immunol. 3 570-575 (2002).

24. Coffey, F., Alabyev, B. \& Manser, T. Initial clonal expansion of germinal center B cells takes place at the perimeter of follicles. Immunity 30, 599-609 (2009).

25. Jacob, J. \& Kelsoe, G. In situ studies of the primary immune response to (4hydroxy-3- nitrophenyl)acetyl. II. A common clonal origin for periarteriolar lymphoid sheath-associated foci and germinal centers. J. Exp. Med. 176, 679-687 (1992).

26. Kuwano, Y. et al. CD83 influences cell-surface MHC class II expression on B cells and other antigen-presenting cells. Int. Immunol. 19, 977-992 (2007).

27. Garside, P. et al. Visualization of specific B and T lymphocyte interactions in the lymph node. Science 281, 96-99 (1998).

28. Chen, Z., Koralov, S. B., Gendelman, M., Carroll, M. C. \& Kelsoe, G. Humoral immune responses in $\mathrm{Cr} 2-/-$ mice: enhanced affinity maturation but impaired antibody persistence. J. Immunol. 164, 4522-4532 (2000).

29. Liu, D. et al. T-B-cell entanglement and ICOSL-driven feed-forward regulation of germinal centre reaction. Nature 517, 214-218 (2015).

30. Tas, J. M. et al. Visualizing antibody affinity maturation in germinal centers. Science 351, 1048-1054 (2016).

31. Bannard, O. et al. Ubiquitin-mediated fluctuations in MHC class II facilitate efficient germinal center B cell responses. J. Exp. Med. 213, 993-1009 (2016).

32. Draghi, N. A. \& Denzin, L. K. H2-O, a MHC class II-like protein, sets a threshold for B-cell entry into germinal centers. Proc. Natl Acad. Sci. USA 107, 16607-16612 (2010)
33. Krzyzak, L. et al. CD83 modulates B cell activation and germinal center responses. J. Immunol. 196, 3581-3594 (2016)

34. Turner, J. S., Benet, Z. L. \& Grigorova, I. L. Antigen acquisition enables newly arriving $\mathrm{B}$ cells to enter ongoing immunization-induced germinal centers. $J$. Immunol. 199, 1301-1307 (2017)

35. Turner, J. S., Marthi, M., Benet, Z. L. \& Grigorova, I. Transiently antigenprimed B cells return to naive-like state in absence of T-cell help. Nat. Commun. 8, 15072 (2017).

36. Mayer, C. T. et al. The microanatomic segregation of selection by apoptosis in the germinal center. Science 358, eaao2602 (2017).

37. Schmidt, A. G. et al. Immunogenic stimulus for germline precursors of antibodies that engage the influenza hemagglutinin receptor-binding site. Cell Rep. 13, 2842-2850 (2015).

38. Liao, H. X. et al. Co-evolution of a broadly neutralizing HIV-1 antibody and founder virus. Nature 496, 469-476 (2013).

39. Bonsignori, M. et al. Maturation pathway from germline to broad HIV-1 neutralizer of a CD4-mimic antibody. Cell 165, 449-463 (2016).

40. Haynes, B. F., Kelsoe, G., Harrison, S. C. \& Kepler, T. B. B-cell-lineage immunogen design in vaccine development with HIV-1 as a case study. Nat. Biotechnol. 30, 423-433 (2012).

41. Yang, G. et al. Identification of autoantigens recognized by the $2 \mathrm{~F} 5$ and $4 \mathrm{E} 10$ broadly neutralizing HIV-1 antibodies. J. Exp. Med. 210, 241-256 (2013).

42. Rohatgi, S., Ganju, P. \& Sehgal, D. Systematic design and testing of nested (RT-)PCR primers for specific amplification of mouse rearranged/expressed immunoglobulin variable region genes from small number of B cells. J. Immunol. Methods 339, 205-219 (2008).

43. Tiller, T., Busse, C. E. \& Wardemann, H. Cloning and expression of murine Ig genes from single B cells. J. Immunol. Methods 350, 183-193 (2009).

\section{Acknowledgements}

We thank D. Liao, X. Nie, G. Venturi, W. Zhang, X. Liang, H. Peng, and A. Miller for technical assistance and Dr. M. Huang for myeloid cell analysis. This work was supported by NIH awards AI117892 and AI100645 (to G.K.).

\section{Author contributions}

C.-H.Y., T.N., M.K. and G.K. designed the research, C.-H.Y. and T.N. performed the experiments, C.-H.Y., M.K. and G.K. analyzed data, and C.-H.Y. and G.K. wrote the manuscript. G.K. directed the study.

\section{Additional information}

Supplementary Information accompanies this paper at https://doi.org/10.1038/s41467 018-03382-x.

Competing interests: The authors declare no competing interests.

Reprints and permission information is available online at http://npg.nature.com/ reprintsandpermissions/

Publisher's note: Springer Nature remains neutral with regard to jurisdictional claims in published maps and institutional affiliations.

Open Access This article is licensed under a Creative Common Attribution 4.0 International License, which permits use, sharing, adaptation, distribution and reproduction in any medium or format, as long as you give appropriate credit to the original author(s) and the source, provide a link to the Creative Commons license, and indicate if changes were made. The images or other third party material in this article are included in the article's Creative Commons license, unles indicated otherwise in a credit line to the material. If material is not included in the article's Creative Commons license and your intended use is not permitted by statutory regulation or exceeds the permitted use, you will need to obtain permission directly from the copyright holder. To view a copy of this license, visit http://creativecommons.org/ licenses/by/4.0/

(C) The Author(s) 2018 